Historic, Archive Document

Do not assume content reflects current scientific knowledge, policies, or practices. 



\section{PLANTERs' GUIDE} for THE SOUTHLAND

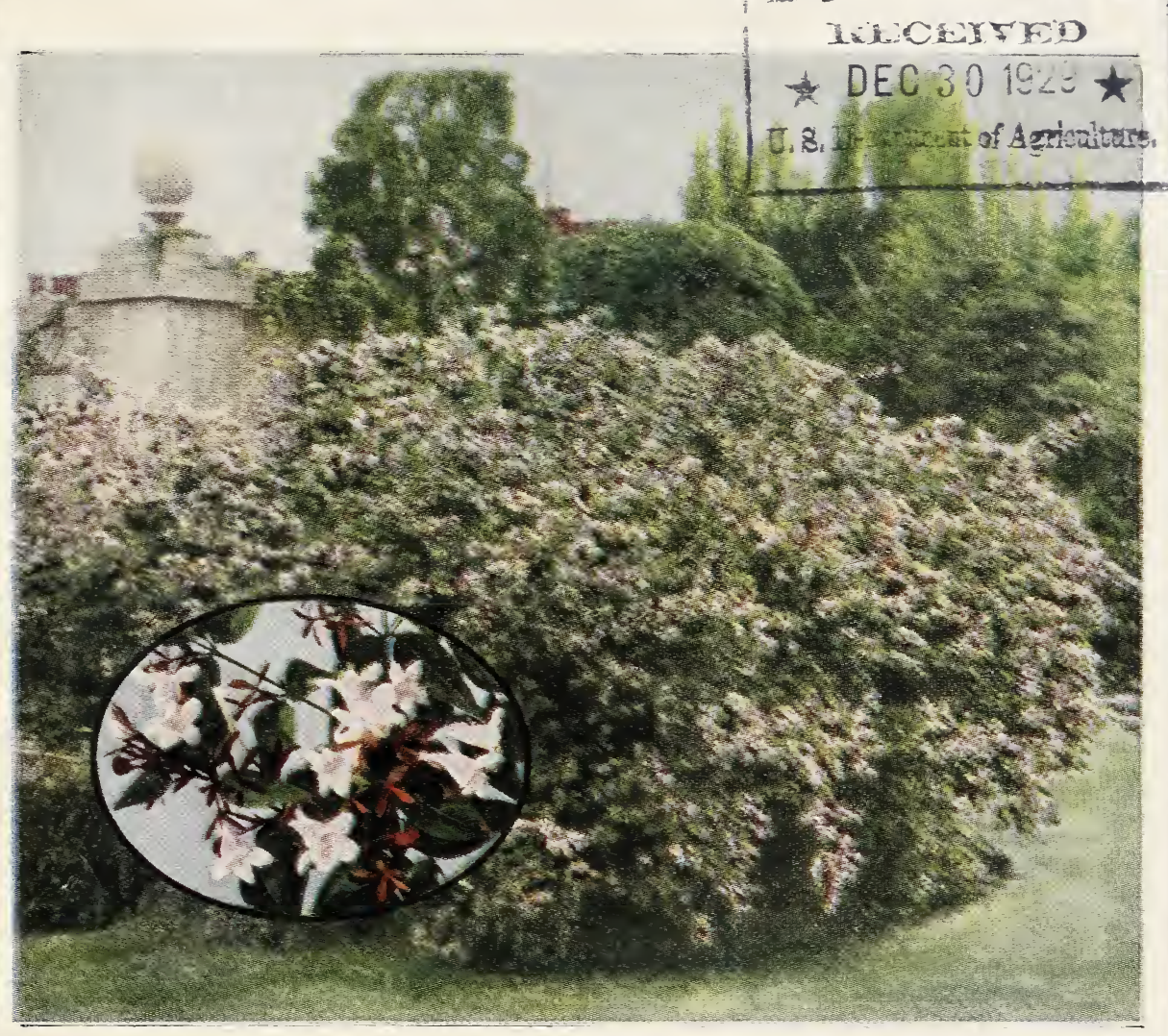

The South's Best Shrub, "Abelia Grandiflora."

We Make a Specialty of Pecan Trees

Wight Nursery and Orchard Co.
J. B. WIGHT, Proprietor
$-:-$
CAIRO, GEORGIA 


\section{MY AIM IS to SELL FRUIT TREES that Make BEAUTIFUL ORCHARDS and ORNAMENTAL PLANTS That MAKE BEAUTIFUL GROUNDS}

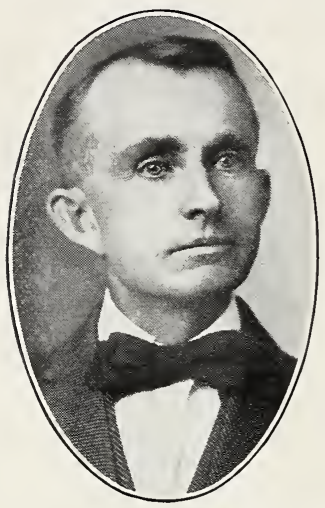

J. B. WIGH'T

We are entering our forty-third season as nurserymen. During the whole period we have been in the nursery business, we have tried at all times to give our customers the very best value obtainable in nursery stock-strong, vigorous trees and plants, true to name-the very best that care and attention and good soil can grow. We feel that we have done this, and that our customers have profited from their dealings with us.

And so it is with genuine pleasure that we enter into another season, because we feel that we are better equipped and better prepared to render our customers the very best service. Our nursery has been rapidly expanding within the past few years, and we are offering this year many items which we have not heretofore listed. All of them have been tested, however, and proven desirable for the South.

In presenting our 1929-30 catalogue, we hope that it will be of service to you, whether it be in helping establish a successful nut or fruit orchard, or in making your house a home through beautification.

AN INVITATION TO VISIT US-I'll tell you what you do-plan to visit our nurseries and see for yourself our fine pecan trees, other fruits and ornamental plants-then you'll understand why people buy from us year in and year out.

\section{WIGHT NURSERY \& ORCHARD CO.,}

October 1, 1929.

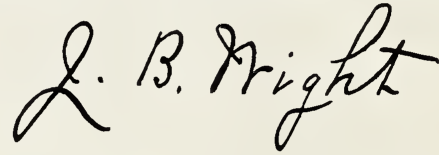

\section{IT IS EASY TO ORDER from WIGHT'S}

\section{READ BEFORE ORDERING}

$\mathbf{W}^{\mathrm{s}}$

HEN TO PIANT-Planting can be done any time the trees and bushes are dormant and the ground not frozen. In the South the best season for transplanting is usually from November 15 to April 1 st.

WHEN TO ORDER-It is best to order early, as this enables us to reserve for you the varieties you want and avoids the possibility of our being sold out. The time of shipment may be left to us, as we keep track of weather conditions throughout the country and ship each order so as to reach our customers at the very best time for planting in that locality. If it is necessary that an order arrive on a certain date, please note it on your order sheet and we will ship to arrive as near to that date as possible.

TERIS OF PAYMENT-Cash with order, or satisfactory reference before shipment; or if preferred, will ship goods with Bill of Lading attached to Sight Draft, through express or bank. On all C. O. D. and Sight Draft Orders we require 25 per cent of the bill before shipment.

PRICES-All prices quoted are net. We offer no premiums, discounts, or gratuities.
Five trees or plants of a class will be billed at the 10 rate; 50 trees at the 100 rate; 500 at the 1,000 rate.

CIUB ORDERS-It is advisable to order all your wants at one time. This will save you time in handling and planting. If your wants are few, have one or more of your friends and neighbors join with you in ordering. We will tie and tag each person's order separately and bundle all together in one package, and ship to whatever address you desire.

HOW TO SEND MONEY - An express money order, postal money order, or bank draft is the best form of remittance. You can send your personal check if you desire. It is not safe to send silver or bills except in a registered letter.

\section{OUR GUARANTEE}

We guarantee our stock to be well grown, true to name, and properly handled and packed. Our responsibility ceases upon delivery to transportation company. All claims should be prompt1y made. 


\section{REASONS WHY PEOPLE
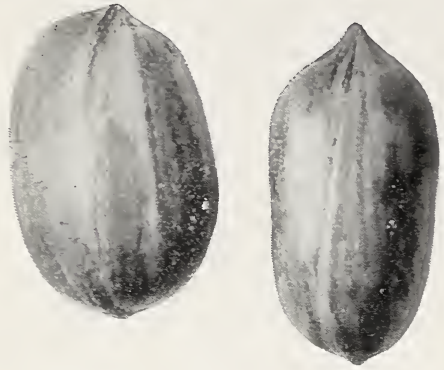 \\ PREFER \\ WIGHT- \\ GROWN \\ NURSERY STOCK}

DEPLE realize that the success of the orchard is determined by the character of the transplanted tree. A runt in the nursery never grows into a giant in the orchard. It is, therefore, important to begin with the best obtainable nursery stock. The following distinctive features characterize my nursery practice-

1. The stock determines, to a great extent, the rigor and fruitfulness of the future orchard. I have found what seems to be the best for this purpose, a budded variety which produces an exceptionally strong and prolific orchard tree. These nuts are used in growing stock for budding purposes.

2. My trees are not dug and "heeled" in to await a customer. This and other precautions account for the promptness with which they generally grow off when carefully transplanted.

3. While we!l grown, my nursery trees are not over-stimulated by applications of excessive quantities of fertilizers.

4. To transplant successfully, a pecan tree should have a good lateral root system. Trees grown on sandy soil usually have an abnormally large tap root with few well-developed laterals. Being grown on a stiffer soil than that generally used for growing pecan trees, my nursery stock is the equal of any and superior to most.

5. There is no nut grass in my nursery.

6. A tree with an older root than four years (most of my tree have three year roots) is never sent out. If a tree hasn't sufficient vigor by that time to be marketable, it is dug up and burned. The setting of dwarfish trees with roots five to six years old accounts for the failure of many pecan orchards.

7. The experience of most orchardists is that a budded tree is better than a grafted one. In particular it is less subject to winter-killing. This being the case I have entirely discarded grafting. The chief reason why many nurserymen still adhere to grafting is because a tree can be grown more cheaply by grafting than by budding.

My first aim is to produce trees that will give satisfaction when transferred to the orchard, and then to sell them at reasonable prices-and that is why we have so many loyal customers.

\section{The Wight Nursery and Orchard Co. Cairo - - Georgia}




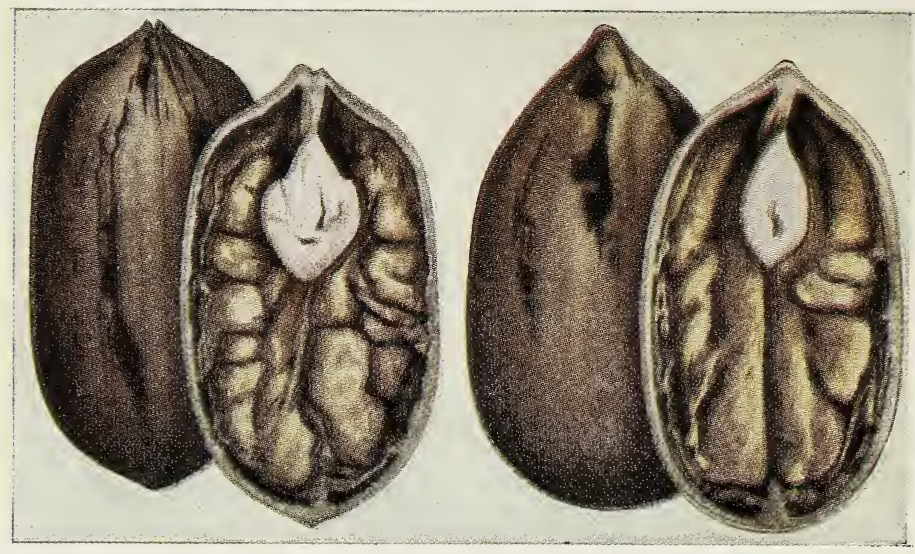

Stuart.

Success.

\section{Here are My VARIETIES and PRICES}

I am testing about forty of the most promising varieties of pecans. The following I consider among the best of these:

FROTSCHER. A large, thin-shelled nut, which has been widely planted. Placed by some at head of list of profitable varieties. MONEYMAKER. An early and prolific bearer, and a healthy, vigorous grower. It is proving a very profitable commercial variety.

MOORE. Nut of medium size; a vigorous and healthy grower; very early and a prolific bearer.

NELSON. This is probably the largest pecan grown. It is a strong, vigorous grower, and an early and abundant bearer. Thickshelled.
PABST. A safe nut to plant. While not quite as large as some of the above, it is a good bearer and one can hardly make a mistake in setting it.

SCHLEY. This variety is placed by some at the head of the list. It is a large, thinshelled nut of fine flavor, and is well filled with meat. Liable to scab near the coast. STUART. An old favorite that has been widely tested. This is a variety that can be planted with safety and succeeds over a wider territory than probably any other kind.

SUCCESS. This is a pecan of fine flavor. Originating in Mississippi, it has been widely disseminated during the last few years.

\section{PRICES 1929-30-ORDER TODAY

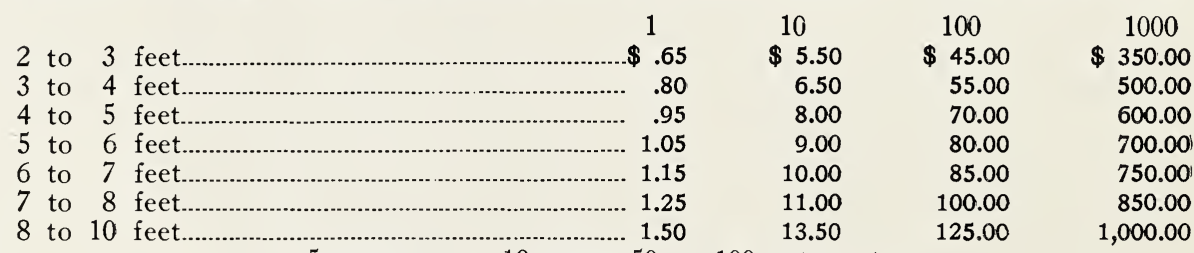

5 trees go at 10 rates, 50 at 100 rates, etc.

NOTE: If in doubt, let us select the varieties for you.

\section{Pecans Add Value to Your Land}

The value of a pecan orchard is hard to estimate. I know several which cannot be bought for $\$ 500.00$ to $\$ 1,000.00$ per acre, because they are yielding a net income of 8 per cent. or more on this amount. I have one tree set in 1892 , which, for the last sixteen years has borne 4,066 pounds of nuts that at forty cents per pound (the average price at which they have sold) has yielded an average of $\$ 100.00$ per year. Is not this tree alone worth $\$ 1,000.00$ ?

Write for cultural directions and other information regarding pecans. 


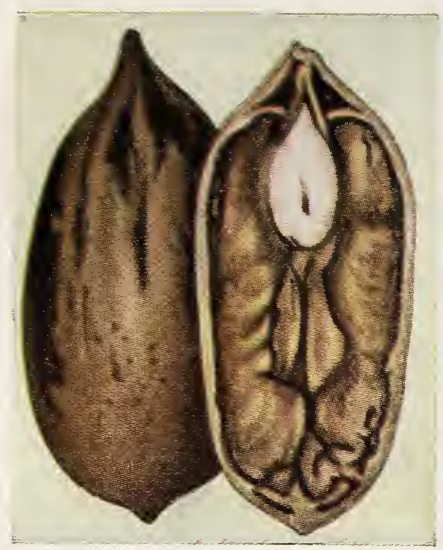

\section{PECANS}

Will Make You More

Profit Than Almost

Anything Else You

Can Grow

A RE you satisfied to make a small profit from your land when a larger one is possible? If you are not now growing pecans you are not getting all the profit possible from your land. This may strike you as being a strong statement but it is a true one and I can prove it to your entire satisfaction.

In my correspondence files are scores of letters telling of profits derived from an orchard of my pecan trees-profits which would not be possible with but few other agricultural or horticultural products. Just a very few of these letters are quoted on page 12-enough to convince any thinking man that he is passing up his greatest potential money-maker if he does not make the start by setting out a pecan orchard of his own.

\section{A Few Dollars Invested Now Means Independence Later}

I know of no other thing offering such rich rewards, for which the initial investment is smaller. A comparatively few dollars invested now may bring you independence later.

Do you know that right now. throughout the pecan belt, there are individual trees that are worth from $\$ 500$ to $\$ 1,000$ each? This value is REAL for it is based on an 8 per cent annual income from these amounts. A tree yielding an average crop of $\$ 50$ worth of nuts, allowing $\$ 10$ for gathering and marketing, is well worth $\$ 500$. this being 8 per cent of that amount.

Suppose in later years that you have 50, 100, or more such trees-what will it mean to you? Make up your mind right now to enter this highly profitable field and let me help you to get started right!

\section{NEVER SAW BETTER TREES}

"I bought from you in January, 1926, four Schley pecan trees 8 to 10 feet and set them in nyy yard and they bore about one pound of nuts to the tree in 1928 . Never saw better trees in my life."

J. A. WALL, Waycross, Ga.

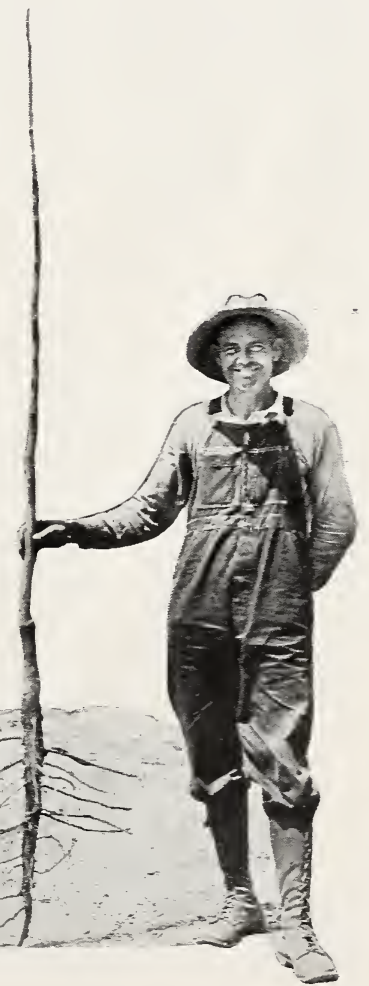




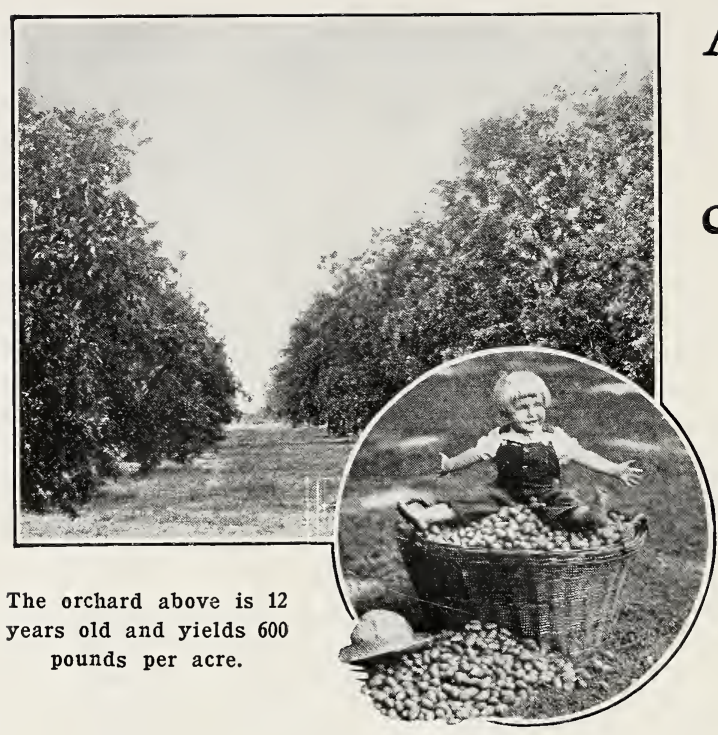

A Pound of PECANS

can be grown more cheaply than a pound of COTTON and what's more you have

twelve months a year in which to sell them

$\mathrm{O}$ NCE an orchard is established, it is an actual fact that a pound of pecans can be grown for less than a pound of cotton-less worry, less work, less rush.

Moreover, there is no need to gather nor dispose of your crop immediately as is the case in most other crops of the cotton belt. They do not suffer in quality or flavor if not gathered for weeks after ripening and you can wait until the market is most favorable before selling them. Pecans, if kept in a cool place, will not deteriorate in quality if kept even for twelve months.

Another big advantage is that they ripen after most crops are harvested and thus add to the length of the season for profitable employment of farm labor.

\section{My Plan for Going into the Pecan Business}

The best way to start is to plant one to five acres for each plow operated on the farm.

Inasmuch as tell to twelve years are required before the trees are bearing profitably, another crop, which may safely be interplanted with pecans, should be grown for immediate profits.

Some growers are using Peaches for this purpose. Pecans and Peaches may be grown together successfully, for to a great extent they require the same conditions of soil, culture and fertilizing.

There are other crops which may be safely grown with Pecans, varying with locality and type of soil. I will be glad to give you individual advice on this matter. Some people plant Pecans and cultivate regular crops about them until the nut trees begin to bear.

Whether you plan to grow Pecans on a large or small scale, there are three important requisites for successful growing. FIRST: Only strong vigorous budded trees of such varieties as are best adapted to the section where they are to be grown, should be set. Avoid stunted trees, for a runt in the nursery will remain a dwarf in the orchard. SECOND: Set trees only on the best land. THIRD: Cultivate, fertilize and care for them in the best manner.

\section{My Trees are Sure to Grow}

If planting directions are followed and proper attention and care given, my trees usually grow.

Great care is taken to send out only strong, vigorous, well rooted trees. The varieties I send are true to name. Only strong, vigorous stocks are used for propagating purposes. Scions are taken from my own trees which may be seen growing and fruiting in $m y$ groves. Start right with trees from Wight! 


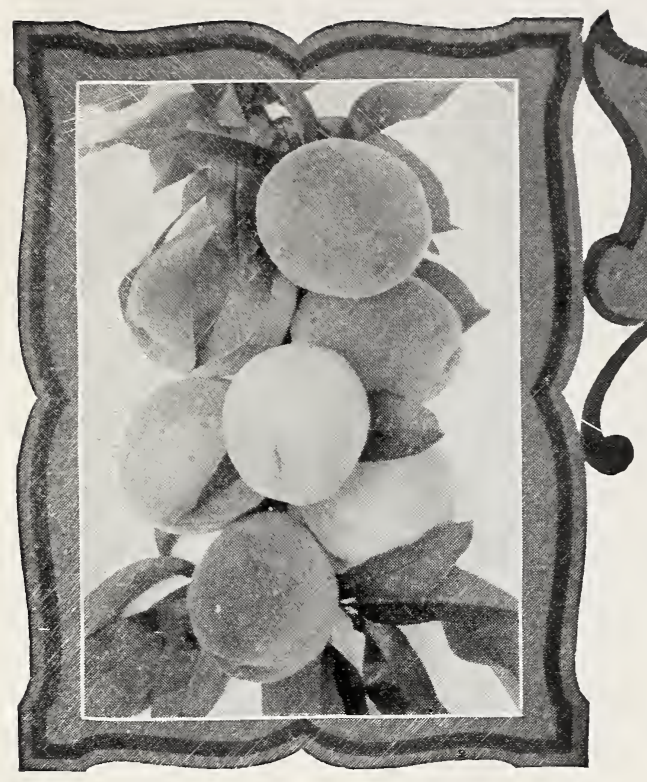

\section{PEACHES}

\section{Southland's Leading Fruit}

THE peach has long been a favorite orchard fruit of the South. It matures quicker than other ratively early. Its large range of varieties makes it possible to have fruit ripening over a long period of time in the same vicinity.

Every farmer and home-owner should have at least a few trees. Often a small orchard of four or five acres will prove quite profitable for supplying your home market, even near very small towns. The peach is a popular "filler" crop to be grown in pecan orchards before the pecan trees come into commercial production.

Peaches will grow over a wide territory of the South. Of the many varieties of peach trees, we have selected and are listing those proving most satisfactory over the largest territory in the South. They give a long fruiting period in practically any territory suited to peach culture.

Peaches have one requisite wherever they are grown-they must be planted on well drained soil. Varieties are listed in order of ripening.

SOME HINTS FOR THE CULTURE OF PEACHES Plant one-year-old trees about $18 \times 18$. Prune severely, cutting back 18 to 24 inches to form a balanced, low, and compact head. The following Spring cut away all but three well distributed branches. The annual pruning should consist of cutting off about one-third of the last year's growth Don't let the branches get too long as their weight will split the tree trunk. Dehorning is done only when there has been a bad winter freeze.

MAYFLOWER. Earliest peach known, although a late bloomer. Medium size, entirely covered with red. Good shipper. May 15th to June 1st.

EARLY ROSE. Because of its excellent keeping and shipping qualities, this is an important and very desirable early peach. Medium size, highly colored. May 20th to June 10th.

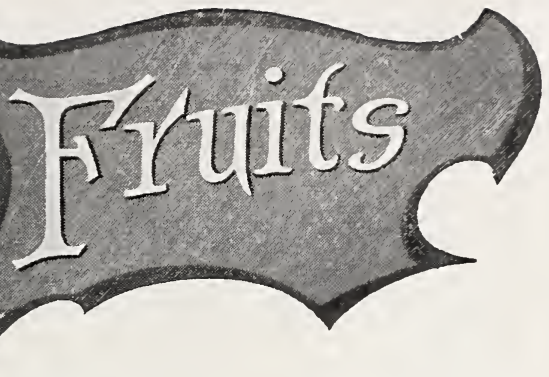

HILEY. Large, red cheeks, flesh white, red at pit. Freestone. June 20th.

CARMAN. Large, creamy-white, tinged red. Freestone. June 20th.

GEORGIA BELLE. Large, showy, clear creamywhite, tinted red. Flesh white and firm. Excellent quality. Freestone. July 1 st to 15 th.

ELBERTA. Probably best known of all peaches. Very large; yellow skin with red cheek. Flesh yellow and juicy. No orchard should be without this variety. Middle of July.

EARLY CRAWFORD. An early yellow-fleshed peach. A very handsome variety with yellow skin, having a dark red blush. Quality unsurpassed, a good Peach for market or home orchard. Tree large and vigorous, bearing in early September.

Size

PRICES

$\begin{array}{rlrr}\text { Each } & 10 & 100 \\ \text { June Buds, } 2 \text { to } 3 \text { feet........... } \$ .35 & \$ 2.50 & \$ 20.00\end{array}$

One year, 3 to 4 feet............ $.50 \quad 4.00 \quad 25.00$

FRUITS AS FILLERS IN PECAN ORCHARD

A quite popular practice among orchardists is to use some quick bearing fruit trees as fillers among pecan trees in the orchard so that the land will in a short time be bringing a profit. The fruit trees are removed as soon as the pecan trees begin to bear or are crowding. An excellent plan is to plant the pecan trees 60 hy 60 feet, and to interplant with fruit trees 20 by 20 feet apart. Such a plan allows approximately 12 pecan trees and 98 fruit trees per acre. Peach, apple, pear, persimmon and plum trees are a!1 excellent for this purpose.

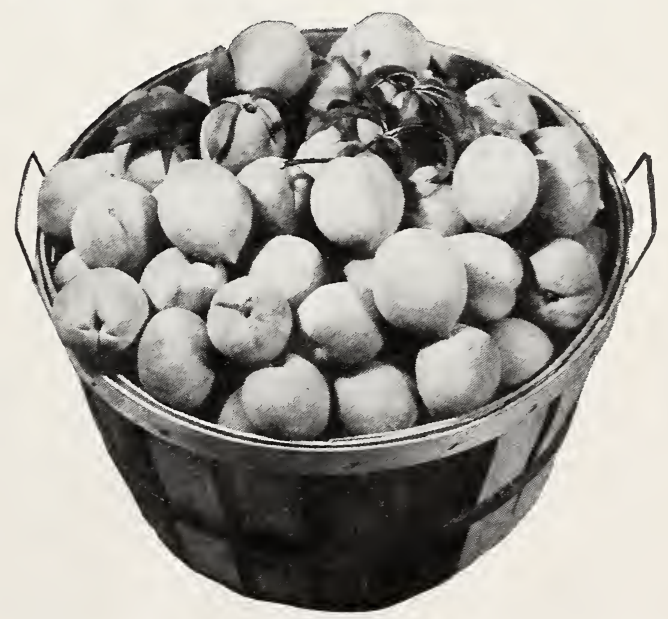

Elberta Peaches. 


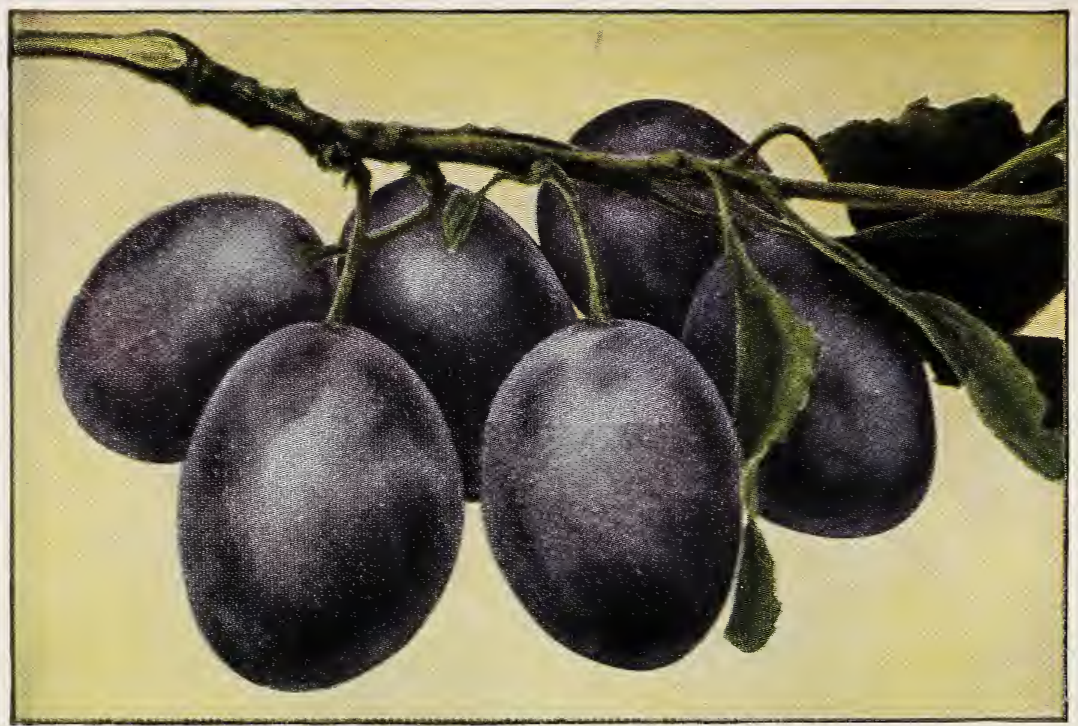

Damsons.

\section{PLUMS}

Recent plum crops demonstrated the fact that plum culture in the South offers wonderful opportunities for profit. The plum bears young and regularly, is about the most productive of the fruits, and very easy to grow. The increasing popularity of this fruit, both in the fresh state and for commercial preserving purposes, enables the grower to market plums readily and at fancy prices in Northern and Southern markets. The demand for plums for refrigerator car shipments is increasing and commercial plum growing offers itself as an enterprise both profit and pleasure producing.

Plum trees should be planted 15 to 25 feet apart each way and can be used, if desired, as a filler in an orchard between permanent trees. It is desirable to plant plums in poultry yards as the nitrogenous fertilizer furnished by the chicken manure seems to be just what the trees need; also the fowls clean up the curculio that attacks the fruit.

BURBANK. Very large, clear rich red, showing yellow dots. Flesh deep yellow, firm and meaty.

DAMSON (Shropshire Damson). Fruit dark purple. of medium size. Tree very productive. A good preserving variety.

RED JUNE. Vigorous grower. Prolific. Medium to large. Deep vermilion red, showy. Flesh light lemon yellow, slightly sub-acid. June.

WICKSON. Very large, deep maroon-red; popular Japanese variety; flesh very firm, yellow, cling, sub-acid, rich. An excellent variety, but too often a shy bearer.

KELSEY JAPAN. Very large, heart shaped, greenish yellow, sometimes spotted red. Vigorous grower, prolific bearer, good quality. July.

\section{PRICES}

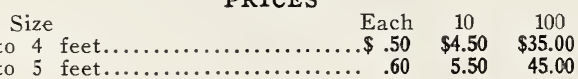

WINESAP. A recent introduction which is growing rapidly in favor wherever it is known. A very thrifty grower, far surpassing other plums. It is not uncommon for trees in the nursery row to make eight to ten feet of growth the first year after budding. Fruit deep red when half ripe, blending into dark purple as it ripens. Juicy; cling; very large; some specimens reach a diameter of $2 \frac{1}{2}$ inches. Sweet-acid when ripe with slight tang, not at all unpleasant in the ripe fruit. One of the best keepers and shippers. July 1st to 15 th.

\section{PRICES-WINESAP PLUMS}

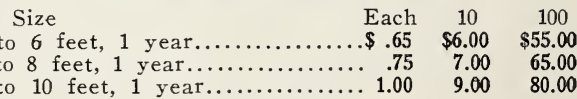

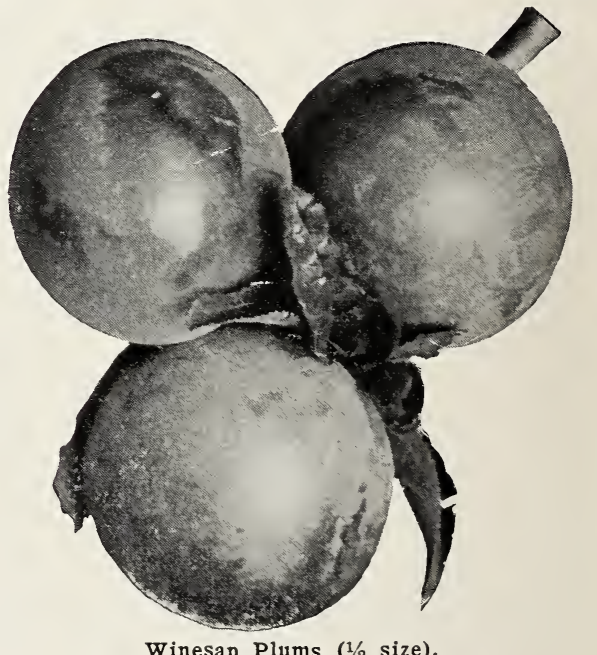

Winesap Plums ( $1 / 2$ size). 


\section{PEARS}

The number of varieties of pears that can be satisfactorily grown in the South has been greatly reduced in recent years due to the high susceptibility of most varieties to blight. No spray has been developed which is effective in controlling blight, so that the only control method now recommended is pruning out diseased limbs. The chief effort in pear culture lately has been the introduction of blightresistant varieties. A number of these are being tested now. Many of them may prove valuable. However, the Pineapple pear is at the present time the outstanding blight-resistant pear.

PINEAPPLE. The pineapple pear's blight-resistant qualities make it in great demand as an orchard tree in the South. A very vigorous grower and unusually heavy and regular bearer. The fruit is large and attractive; flesh coarse, juicy. Its quality is very similar to that of the Keiffer. Although not recommended for eating raw, it makes an excellent canning and preserving pear. Ripens during July and August.

KEIFFER. Fruit large to very large. Skin yellow, flesh brittle and juicy. Good quality fruit maturing in September and October. Trees vigorous and prolific.

\section{PRICES}

Size

Each

10

100

2

2 to 3 feet...................\$.35

3 to 4 feet.................... .45

4 to 5 feet.................. 50

5 to 6 feet................... 60

$\$ 3.00 \$ 25.00$

$4.00 \quad 35.00$

$4.50 \quad 40.00$

$5.50 \quad 50.00$

\section{JAPANESE PERSIMMONS}

For a number of years the Japanese Persimmon has been gaining in popularity. It has been grown in the cotton belt sufficiently long to show that it is well adapted practically all over the belt, at least where the native persimmon thrives. In recent years it has become better known in the Northern and Eastern markets and has commanded very attractive prices wherever it was offered. Leading orchardists in the South are recognizing its possibilities and the chances are that within a few years Japanese Persimmons will be known and marketed in all the leading cities of this country.

Some varieties of Japanese Persimmons, under certain conditions, are self-pollenizing, but it has been found advisable to plant among the other varieties, the staminate variety called Gailey. One tree of this variety to ten trees of the other varieties will insure good pollenization and fruit will grow on to maturity.

FUYUGAKI. A recent introduction from Japan. Tree vigorous, upright grower; fruit medium to large, nearly round, but somewhat flattened; skin smooth, tough; color reddish yellow. Flesh meaty and of exceptionally good flavor. Bears young. Non-astringent; can be eaten while still hard; may be peeled and eaten like an apple.

TAMOPAN. A Chinese variety of special merit. Fruit is large, somewhat flattened and with a compressed ring around it as though a string had been tried around the fruit while growing. Color beautiful golden red; skin quite thick and tough.

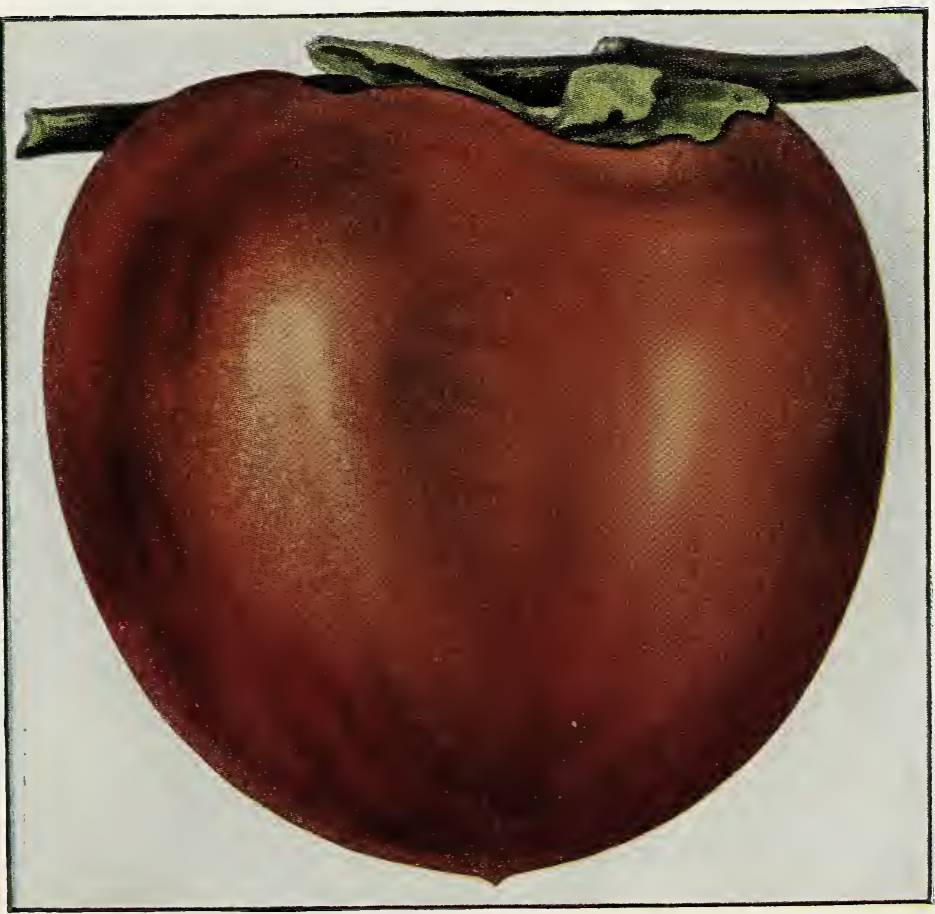

Japanese Persimmon.
TA NE NASHI. The best known and probably the most popular variety. Large to very large, roundish, conical, point ed; skin light yellow, changing to deep red. Quality very fine. The leading market variety.

GAILEY. Recommended for its staminate flowers for pollenizing and not for its fruit. Fruit small, color dull red; flesh dark about the seeds, meaty, juicy. Should be in every planting.

\section{PRICES}

Size Each $10 \quad 100$

2 to $3 \mathrm{ft}$...\$ $.35 \$ 3.00 \$ 25.00$

3 to $4 \mathrm{ft}$... $.50 \quad 4.50 \quad 40.00$

$\begin{array}{lllll}4 & \text { to } 5 \mathrm{ft} . . & .65 & 6.00 & 55.00\end{array}$

$\begin{array}{lllll}5 & \text { to } 6 \mathrm{ft} . . . & .75 & \mathbf{7 . 0 0} & \mathbf{6 5 . 0 0}\end{array}$

\section{SPECIAL OFFER NO. 3}

\section{Fruits For Home Garden}

2 Pecans, 3 to 4 feet

3 Peaches, 3 to 4 feet

1 Pineapple Pear, 3-4 ft.

1 Plum, 4 to 5 feet

\section{Plants}

Regular Price . . $\$ 4.20$

Special Offer, Price . $\$ 3.75$ 


\section{CITRUS FRUITS}

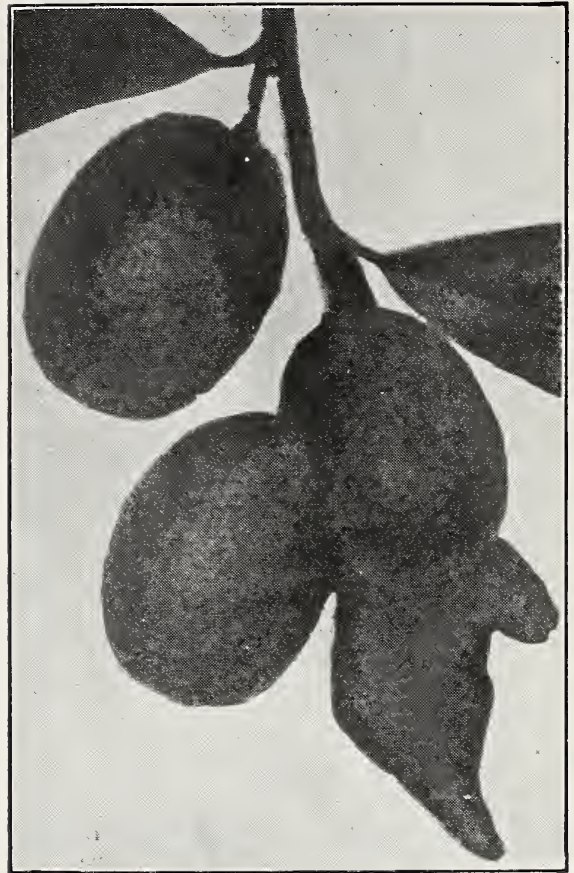

Kumquats.

Only a short time ago it was thought that citrus fruits could not be grown outside of the tropical or semi-tropical zones. With the successful introduction of the Satsuma orange to this country, the area in which citrus fruits can be profitably grown has been gradually spreading, so that now many citrus fruits are grown where it was once thought impossible. In our orchards here at Cairo, we have producing orchard trees of Satsuma orange, Grapefruit, Kumquat, Meyer Lemon, and Citrangequat. Although Cairo is near the northern limit of the zone in which they can be profitably produced, we have a small grove ten years old which has demon. strated fully that Satsumas may be grown commercially here. Northern and Western Florida, Southern Georgia, Southern Alabama, and the section along the Gulf Coast offer great possibilities in the production of this valuable citrus crop.

OWARI SATSUMA. Our Satsuma orange trees are of the Owari variety, the one best suited to conditions in this country. We use a root stock the hardy orange, CITRUS TRIFOLIATATA. Satsumas should come into bearing the third year, and into commercial production the fifth year.

\section{Folder on Satsuma Culture.}

We have prepared for our customers in Northern and Western Florida, Southern Alabama, Southern Georgia and the Gulf Coastal sections a little folder in colors called "Satsuma." It discusses in detail the possibilities of profit in growing Satsumas, methods of culture, etc. We shall be glad to send you "Satsuma" on request.
SATSUMA ORANGE (C. nobilis owari). The Satsuma is the hardiest of the oranges and has all the good qualities of the best California and Florida oranges. It begins bearing very young and is the most prolific of all varieties. Aside from the fact that it is easily grown, it has the advantage of being the most deliciously flavored and attractive of the citrus fruits. The flesh is tender, juicy, fine grained, sweet and delicious with a peculiarly agreeable flavor found in no other orange. This orange is entirely seedless, and this fact, together with the ease with which it is peeled, makes it very pleasant to eat. Every one with availab!e space should grow Satsumas. They ripen early in October through November, thus they are subject to little competition from other varieties. Aside from their advantages as a commercial fruit, these oranges can be produced most satisfactorily in the backyard, and furnish delicious fruit to the family in the early winter weather when that class of foods is so desirable and so high priced.

DUNCAN GRAPEFRUIT. This is the hardiest variety being produced extensively at this time. It is not, however, quite so resistant to the cold as the Satsuma orange. The fruit has a very excellent flavor, is medium to large, fine quality and has a very attractive appearance. Ripens early in December. Tree a heavy bearer.

KUMQUAT. This is the smallest of the edible citrus fruits grown in the northern part of the citrus-growing region. The Kumquat is a sweetskinned orange which is very delicious and makes a very choice fruit for desserts, jellies, jams, preserves, pickles and marmalades. Aside from this, the yellow-gold fruit on the small evergreen tree makes a beautiful sight, and the tree is therefore valuable as an ornament. These trees are very hardy, bear enormous yields and never miss a crop; in fact they bear the first season after setting. The fruit is readily marketable.

CITRANGEQUAT (Thomasville). A cross between the citrange and kumquat; about the size of the lime; rapid grower and early bearer. A valuable and attractive novelty.

PRICES, ALL CITRUS FRUITS Each 10

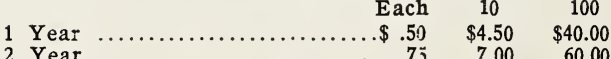

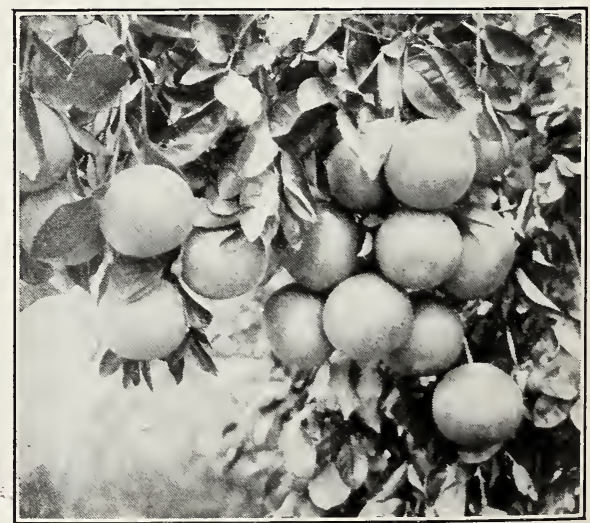

Duncan Grapefruit. 


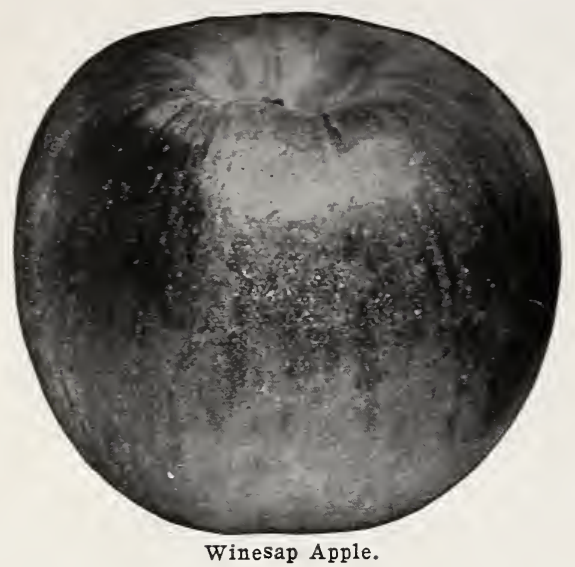

\section{APPLES}

DEIICIOUS. A remarkably popular variety in the West. Fruit large, nearly corered with dull, dark red; fine grained, crisp, juicy; quality best.

HORSE. Large, green, acid. Good for cooking and drying. A productive variety, bearing in July and August.

RED JUNE. Medium, conical; deep red and very juicy. A productive variety, bearing from June 15 th to end of July.

WINESAP. Small to medium; red. vinous, quality very good. A good keeping apple.

YATES. Small dark red, dotted with small white dots; flesh yellow, firm, juicy and aromatic. A heavy bearer and good keeper.

\section{PRICES}

$\begin{array}{llll}\text { Size } & \text { Each } & 10 & 100\end{array}$

2 year, well branched............\$ $.65 \$ \$ 6.00 \quad \$ 55.00$

1 year, well branched............ $.50 \quad 4.50 \quad 40.00$

\section{GRAPES}

Commercial vineyards of bunch grapes for supplying the local market have proven quite profitable in many parts of the South. Although the bunch grape is not native to the South, with proper care it gives excellent results. Vines should be planted 8 to 10 feet apart and trained on a three-wire trellis.

CONCORD. Blue-black, vigorous grower and heavy bearer. One of the old favorites.

DELAWARE. Small to medium sized bunches of small pink berries; in quality one of the best.

MORRILL. Large bunches and berries, very juicy. Vine very vigorous and highly resistant to disease. June 20 th to July 10th.

NIAGARA. Large bunches of good sized white berries; an attractive market variety.

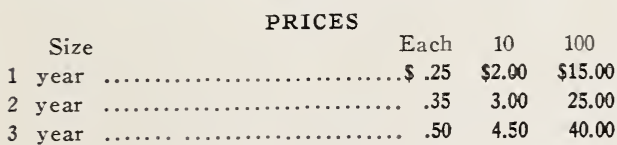

The Muscadine group of Grapes is native to the South and an old favorite. They are well adapted to soil and climate and need no introduction to the South. Muscadine vines are generally trained on overhead trellises, and are spaced 20 to 25 feet apart each way.

SCUPPERNONG (Muscadine). Well known in the South. Large berries, seldom more than eight or ten in a cluster. Brown. thick skinned, pulpy fleshed. Very vinous, sweet and has a peculiar musky aroma. This grape is a regularly bearing variety and the vine is disease-resistant and free from insect depredations. Fruit has never been known to decay before maturity. Very prolific.

THOMAS. Fruit extra large, borne in clusters like Scuppernong. Color purple, thick skin. Fruit has a peculiar tang which is very delightful. A very desirable arbor grape.

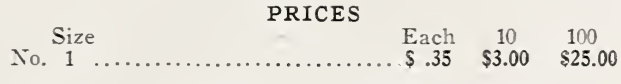

Kudzu is fast becoming the leading hay crop in the Lower South. After it once be comes established, it requires no cultivation whatever. The vines will cure and be ready for baling in less than twenty-four hours after cutting. This is a distinct advantage in the lower South when hay-making time, August and September, are often very rainy months. Planted in 15 foot drills, three feet in the drill, it requires between 800 and 900 roots to plant an acre. Such a plan leaves room for two row's of corn or other crop to be planted between the kudzu rows, so that a crop can be made at the same time the kudzu is cultivated. The following year plant cnly one row of corn. By the third season the kudzu will have become well $\epsilon$ stablished and a good crop of hay can be cut.

Price per 1000 Roots.................. $\$ 15.00$

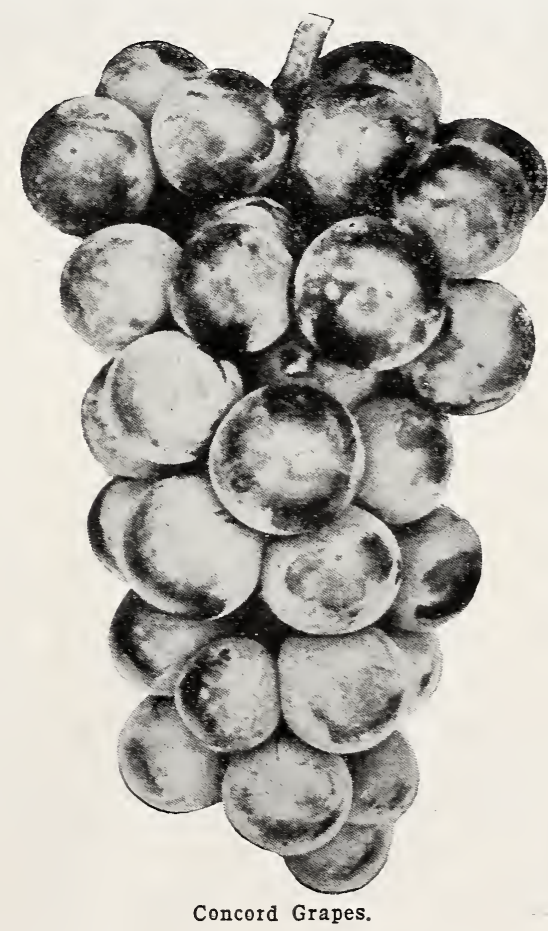




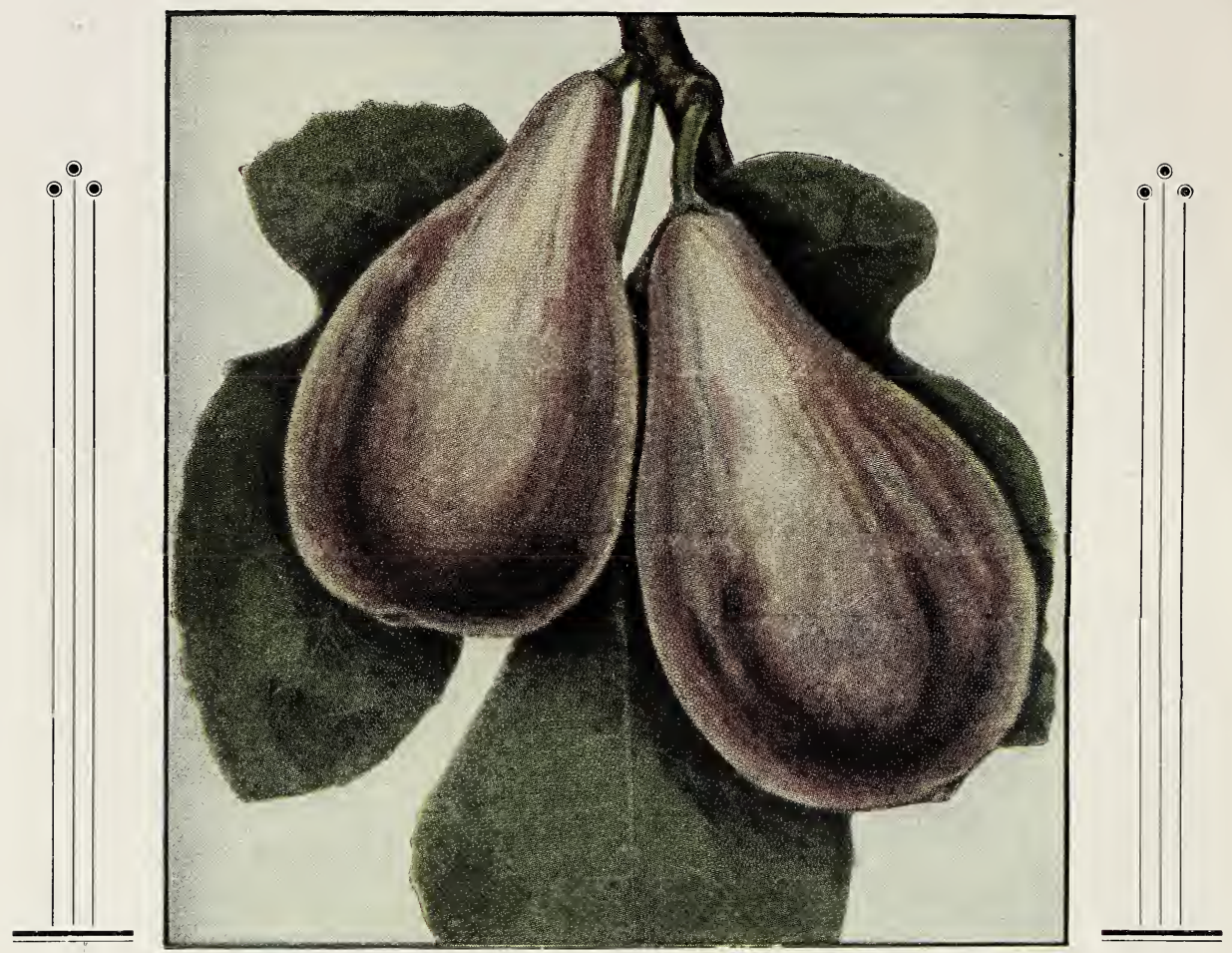

\section{FIGS}

A TRULY Southern fruit of high quality which cannot be grown in the North. This fruit is found almost universally in home plantings in the South. Figs are delicious for eating both fresh and preserved.

Fig trees may be planted as close together as 10 to 12 feet, and require very little cultivation. Cultivation should always be shallow as the roots are close to the surface. Figs seem to do best when their roots can run under buildings. Both varieties we list are very hardy.
BROWN TURKEY. Medium to large; yellowish brown; pulp tender, rich and of the finest quality. Fruit borne on long stems, allowing fruit to hang blossom end down at maturity, preventing souring in rainy weather.

CELESTE. Fruit is of medium size; color pale violet, thin skin and firm flesh. Juicy, rich and sweet. Tree strong grower and reliable bearer. Hardiest of all the Figs.

\begin{tabular}{|c|c|c|c|c|}
\hline Size & & PRICES & 10 & \\
\hline 2 to 3 & feet. &.$\$ .35$ & $\$ 3.00$ & $\$ 25$. \\
\hline to 4 & feet.. & $\ldots . .50$ & 4.50 & 40.00 \\
\hline to 5 & feet.. & .65 & 6.00 & 55.00 \\
\hline to 6 & & .75 & 7.00 & \\
\hline
\end{tabular}

Mrs. L. Lester, Montezuma, Ga.-“Three years ago this month I bought from you four pecan trees, two Stuarts and two Moneymakers. A few days ago I gathered several dozen nuts from the Stuarts; they were fine in size and flavor."

Mr. B. Overstreet, Oliver, Ga.- "My pecan trees that I bought from you are doing fine. I have just finished gathering this crop. My trees are 8 years old this fall and from twenty trees $I$ have gathered 600 lbs. of nuts."

Mr. J. R. Nutting, Atlanta, Ga.- "Your pecan trees have always given entire satisfaction, and the trees that have had the proper attention have yielded fine results."

Mr. T. M. Furlow, Americus, Ga.-"The several hundred trees that I have bought from you through several seasons I have never received one that did not come up to and surpass my expectation. I don't think that I have ever had less than $97 \%$. to live, and I have always bought 5-6 foot trees.

Mr. O. M. Greene, Iron City, Ga._-"The trees I purchased from you three years ago bore this year and the nuts were delicious and well developed. I would not take $\$ 25.00$ apiece for the 18 trees."

Dr. P. C. Quarterman, Valdosta, Ga.- "The Pecan Trees purchased from you three years ago have been highly satisfactory, despite the fact that 15 or 20 of them were destroyed by fertilizer being placed too close to the trunk. ... I have had no other trouble with trees except some injured by rabbits." 


\section{AZALEAS}

$\mathbf{N}$ O Flowering Shrub is so outstanding, so surpassingly beautiful when in bloom as is the azalea. Often practically all the leaves are hidden by the flowers in their riot of color-azaleas may be had in purple-pink, salmon pink, orange red, red flame, deep pink, red, white, and light pink colors. There are a number of varieties of azaleas of different shadings of the same color, so that they offer a wider range of shades and colors than any flowering plant suited to the South. The blooming season may also be lengthened considerably by the selection of several varieties.

The Indian azaleas have the added advantage of being evergreen, so that even when they are not in flower their attractive foliage is an addition to any landscape. Azaleas can be grown successiully along the seacoast of the middle Atlantic states with a little protection to keep the bloom buds from being injured by cold-and very successfully along the coast from Charleston to South Central Florida and around the Gulf Coastal section to Texas without any protection whatever.

Azaleas are very easy to transplant and have few cultural requirements. Azalea roots like a cool soil, and should be planted in a partial shade, at least until the plants become large enough to shade their own roots. They may then be planted in full sun to advantage. Azaleas thrive in an acid soil. Where planted in a region in which the soil is alkali, it is advisable to dig out a good large hole and fill it in with leaf mold or woods earth. The peaty muck found in and around old ponds is very desirable. Where this is not obtainable, or where azaleas have already been planted in an alkali soil, a small amount of aluminum sulphate, 1 pound to 30 square feet, will be found beneficial. Fertilize lightly about twice a year with cotton-seed meal and tankage. Azaleas like à moist soil but it must be well drained.

Do not cultivate around azaleas. Their roots are right on the surface of the ground and any cultivation would be likely to cut a number of feed roots. If weeds appear, pull them up.

Azaleas may be used in almost any location where any other dwarf evergreen could be used. It is attractive in the foundation planting in front of the taller plants; in formal or informal beds, using colors which blend well; in hedges-in fact, anywhere where its beauty may be seen and appreciated.

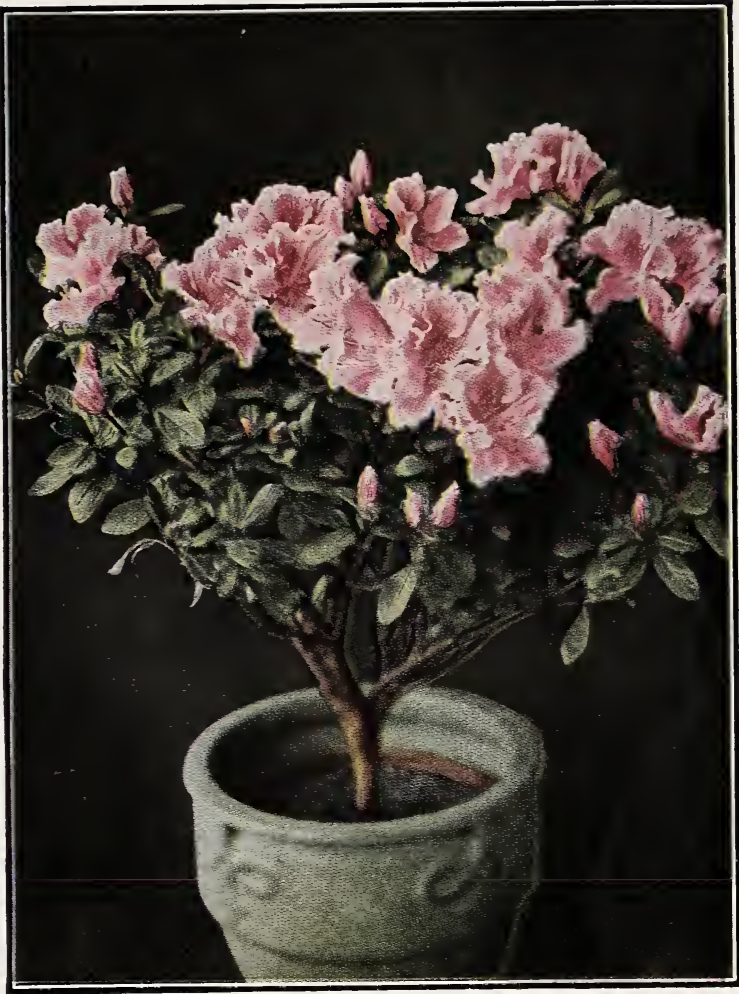

Elegans Azalea.

FIELDERS WHITE. The most satisfactcry white azalea; has large blossom of pure white. Bush vigorous, compact grower. Excellent for grouping with other colors.

FORMOSA. The purple-pink variety so satisfactory in the Southern states. Large single flowers; leaves dark green. Very easy to grow and very vigorous.

RED FLAME. A very brilliant red which flowers early in April. This is one of the most vigorous varieties and may be seen at Magnolia Gardens the size of small trees. A most desirable plant.

\section{PRICES}

Fielder's White, Formosa, Red Flame.

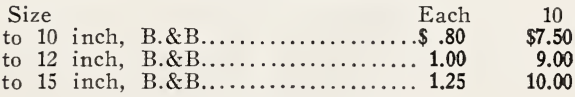

Formcsa, Red Flame Only.

15 to 18 inch, B.\&B............... $1.50 \quad 12.50$

18 to 24 inch, B.\&B.................... $2.00 \quad 17.50$

24 to $30 \mathrm{inch}$, Red Flame only....... 2.50 22.50

AMOENA. Hardy, and very popular in the North; small hose-in-hose pink flowers, with shadings of purple; leaves small, dark lustrous green. Tall grower. At Cairo blooms in fall or early winter.

ELEGANS. A light clear pink with lustrous green leaves; its shadings are very delicate. Early bloomer and very desirable. 
MACRANTHA. A lovely pink flowering azalea valuable for its deep luxuriant green foliage and for the fact that it flowers irregularly throughout the growing season.

PRIDE OF DORKIN. A rather slow growing variety of azalea which blossoms late in the season; flowers a very deep pink which is especially pleasing.

Besides the above named varieties we can supply Azalea Indica in the following colors: Purple, Salmon Red, Orange Red, Deep Pink, and Late Deep Pink.

Size

\section{PRICES}

8 to 10 inch, B. $\&$ B................. $\$ 1.00$

10 to 12 inch, B.\&B................... 1.25

Each
.$\$ 1.00$
1.25
1.50

10

$\$ 9.00$

10.00

12.50

15 to 18 in., Elegans, Salmon Red only. 2.00 17.50

HINODEGIRI. A Kurume azalea which is quite popular, and deservingly so. Foliage deep rich green; the plant is dwarf and very compact. When in bloom the foliage can hardly be seen for the bright carmine flowers which cover the entire plant. An early bloomer which holds its blossoms for several weeks. A most satisfactory variety which we recommend heartily. Hardy at New York.

\section{PRICES}

\section{Azalea Hinodegiri.}

Size

8 to 10 inch

Each

10 to 12 inch
$\$ 1.50$

2.00
Your Home Grounds and You

Every day you are judged by the appearance of your home grounds. The world judges by appearances. Make no mistake about it, you are being judged every day by the appearance of your home grounds.

And especially is this true when the great vogue for beautiful, well-planted homes is sweeping the country.

Haven't you passed a home beautifully planted and well kept, and thought, "I'd like to know the people that live there-they must be people of culture, taste and refinement."

What impression do the neighbors and the passersby get of you from the appearance of your home? Do your gro:inds say to tilose who pass, "Here are people you should be proud to know?"

Let us he'p you, through our Landscape Department, to realize the pleasure and satisfaction of knowing your grounds measure up to modern standards of beauty and good taste.

\title{
HORTICULTURAL BOOKS
}

PECAN GROWING, by Stuckey and Kyle. Full of practical details on the culture, propagation, pest control, harvesting, cracking, and marketing of pecans. Describes the latest practical methods of successful growers. 49 illustrations, 233 pages. . $\$ 3.00$ SHRUBS, by F. F. Rockwell. Here is brief but complete and usable information on the best ways to improve the beauty and value of your home with shrubs. Tells what to select for different combinations and effects, and how to plant, water, mulch, prune, and care for shrubs. 49 illustrations, 76 pages.

$\$ 1.00$

THE DESIGN OF SMALL PROPERTIES, by M. E. Bottomley. Here are 52 carefully designed plans, one cr more of which will give you just the planting layout you want for your home. Each pian is fully describerl and explained so that you can easily 1: odify it to fit any special conditions. A check list of nearly 600 plants showing the height, color, time of bloom, foliage, growing habit, soil requirements, etc., of each one shows you what to plant. 64 illus. trations, 233 pages.
THE ROSE IN AMERICA, by J. Horace McFarland. A complete guide to successful growing, based on Mr. McFarland's own experience and the exchange of ideas with other enthusiasts while acting as editor for the American Rose Society. Contains the newest information on cultivation, pest control, and varieties. 66 illustrations, 233 pages. . . $\$ 3.00$ PRINCIPLES OF FRUIT GROWING, by L. H. Bailey. Practical information for growers of every kind of tree and bush fruits. Tells where to locate the orchard, how to plant, cultivate, prune, spray, and do every nther operation necessary to bring high production. Methods of harvesting, grading, and marketing described. 186 illustrations, 432 pp. . \$2.50 EVERGREENS FOR THE SMALL PLACE, by F. F. Rockwell. All the information you need to make the best use of evergreens is in this handy book, written by one who is himself a home owner and a garden maker. It tells the uses, characteristics, and types of small or dwarf evergrecns, and details of their planting, transplanting, and general care. 67 illusrations, 84 pages. . . . $\$ 1.00$

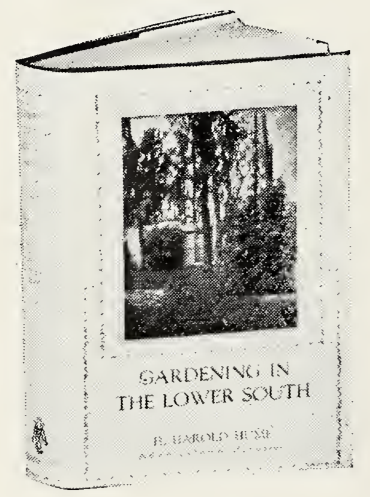

\section{Gardening in the Lower South}

\author{
By H. H. HUME
}

The first and only complete garden guide for the South. It tells what flowers to plant for steady succession of bloom, how to have fresh vegetables throughout the year, how to grow fruits, what varieties to plant, what trees and evergreens grow best, and all about Southern soils, fertilizing, lawn making, palms, roses, azaleas, bulbs, bamboos, vines, and other plants. 102 illustrations, 472 pages.

\section{Price, $\$ 5.00$}




\section{Broad-Leaved EVERGREENS}

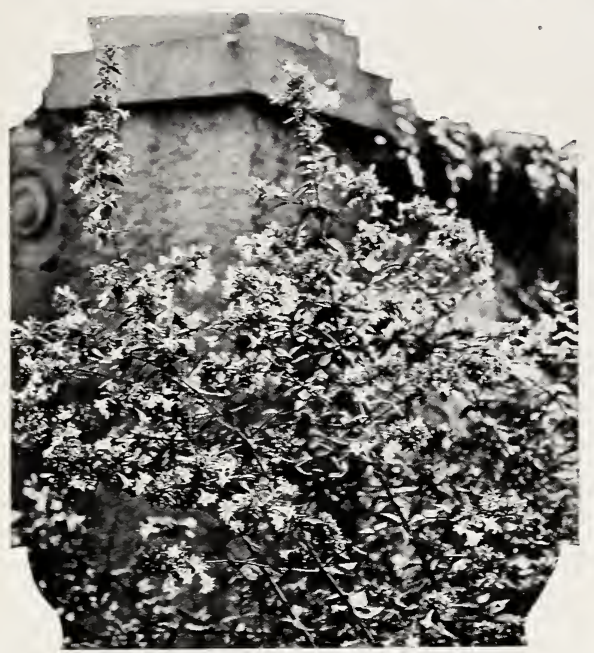

Abelia Grandiflora.

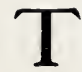

$\mathrm{HE}$ South is indeed fortunate in the wealth of Broad-leaved Evergreens which flourish in practically all sections of it. The broad-leaved evergreens are different from the coniferous evergreens in that their leaves are large and glossy. Many of the broad-leaved evergreens have beautiful blooms and berries-a distinct advantage over the conifers. With the use of broadleaved material one is able to get definite contrasts in color and size of foliage; blossoms over long periods; low growing or tall growing plants as the location demands-in fact. broad-leaved evergreens have all the advantages of conifers without their disadvantages.

Recognizing these facts, there is a very definite trend towards the use of broadleaved evergreens in locations where it was formerly thought only a conifer would suffice. We of the South should give definite study to the possibilities of this great group of plants.

\section{ABELIA}

ABELIA GRANDIFLORA. Succeeding over a rery wide range of climatic and soil conditions, in sun and in shade, this beautiful evergreen is probably the most satisfactory of the broad-leaved group. An excellent plant for hedge work. Although a very rigorous grower, it will stand any amount of pruning. A hardy evergreen, with glossy, dark green foliage. Has profusion of white funnel. shaped flowers, tinted with pink, borne in clusters from May until late Autumn. Valuable for foundation planting, groupings on the lawn, etc.

\section{PRICES}

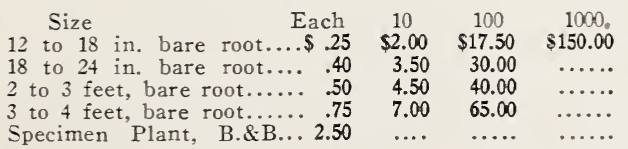

\section{CAMPHOR}

CINNAMOMUM CAMPHORA. This is an unusually attractive shrub with bright, evergreen foliage. It is seldom that one finds a tree or shrub which provides such beautiful color changes. The new growth is a wine color which changes to various other tones until it reaches a dark, glistening green. In fall the older leaves turn a bright red. If allowed to develop naturally will make a broadly rounded cone, branching clear to the ground. Foliage compact. Suitable for windbreaks, hedges or screens. Hardy in the South.

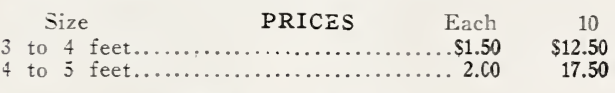

\section{CHERRY LAUREL}

IAUROCERASUS CAROIINIANA. Excellent for a screen, as it is a fast growing, erect evergreen; also for formal work, since the cherry laurel stands pruning especially well. Leaves large, deep green, bright and shiny. Grows to a height of around 30 feet when mature.

\begin{tabular}{|c|c|c|c|}
\hline $\begin{array}{l}\text { Size } \\
\text { to } 18 \text { inch. } \\
\text { to } 24 \text { inch. } \\
\text { to } 3 \text { feet.... } \\
\text { to } 4 \text { feet.... } \\
\text { to } 5 \text { feet... }\end{array}$ & 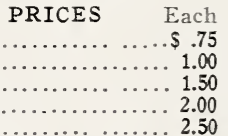 & $\begin{array}{c}10 \\
\$ 7.00 \\
9.00 \\
12.50 \\
17.50 \\
22.50\end{array}$ & $\begin{array}{r}100 \\
\$ 65.00 \\
85.00 \\
100.00\end{array}$ \\
\hline
\end{tabular}

\section{EUONYMUS}

E U O N Y M US JAPONICUS (Evergreen Burning Bush). Leaves dark, glossy green. Sometimes used as hedge. Succeeds in almost any situation.

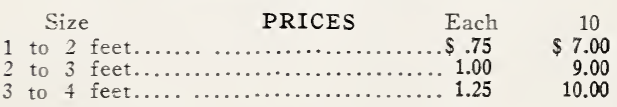

\section{HOLLY}

ILEX OPACA (American Holly Seedlings). Too well known to need description.

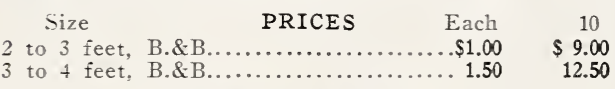

\section{INKBERRY}

ILEX GLABRA. Commonly called in the South, "Gall-berry." An excellent evergreen for use in the shrub border or for hedging. Leaves small, dark, lustrous green; white flowers in clusters which are followed by attractive black berries.

$\begin{array}{lrrr}\text { Size } & \text { PRICES } \quad \text { Each } & 10 & 100 \\ \text { to } 3 \text { feet, bare root............ } \$ .35 & \$ 3.00 & \$ 25.09 \\ \text { to } 4 \text { feet, bare root........... } & .50 & 4.50 & 40.00\end{array}$

\section{JAPONICAS}

CAMEILIA JAPONICA. An old favorite of the South which is coming into greater demand. It has the advantage over most flowering shrubs of blooming in the winter when blossoms are so scarce. Although it is necessary at times to protect the blossoms from cold, their beauty will many times repay the trouble. A dense, symmetrical grower with glossy, deep green foliage. Large, beautiful flowers resembling a full-blown double rose. We can supply in one year in white only, three year in rose-pink only.

Size
1 year plants, 5 in. pots.................\$1.00

\section{PRICES}

3 year plants, rose-pink only, field grown....... 2.00 


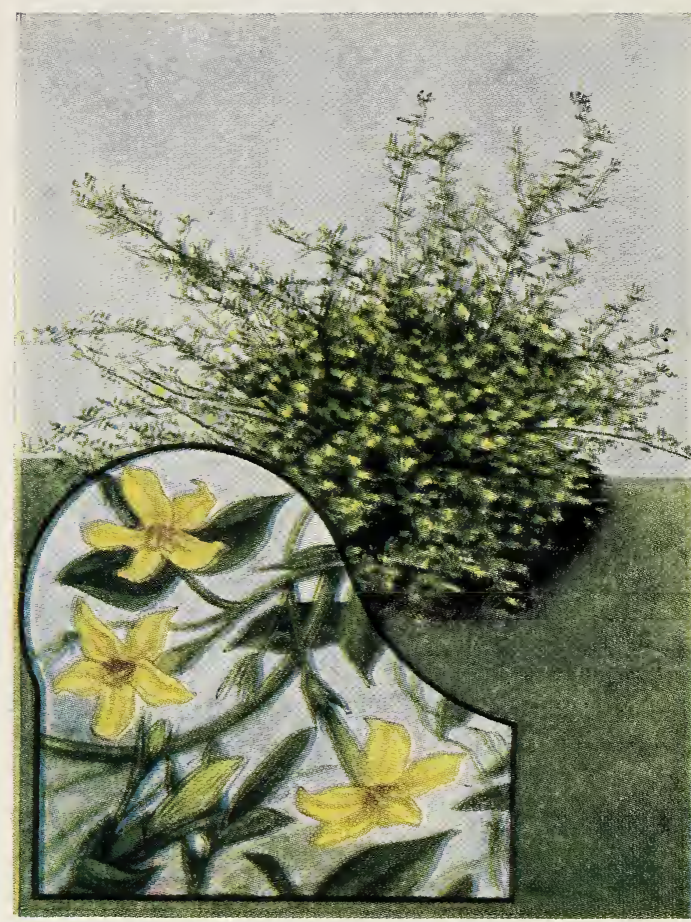

Jasmine.

LIGUSTRUM LUCIDUM. Among the best Ligustrums. Deep glossy green leaves, slightly smaller than L. Japonicum. This plant is a very compact, symmetrical grower, and does well either in shade or sun. Early in May it has panicles of white flowers, which are followed by large clusters of black berries. The berries remain throughout the winter. An excellent plant for grouping and foundation planting. Stands pruning well. Ultimate height, 15 to 20 feet.

\section{PRICES}

$\begin{array}{llll}\text { Size } & \text { Each } & 10 & 100\end{array}$

12 to $18 \mathrm{in,} \mathrm{B. \& B} \ldots \ldots \ldots \ldots . \$ 1.00 \$ \$ 9.00 \$ \$ 80.00$

18 to 24 in. B.\&B........... $1.2511 .00 \quad \ldots$.

2 to 3 feet................. $1.75 \quad 15.00 \quad \ldots \ldots$

\section{MAGNOLIA GRANDIFLORA}

See page 30 .

\section{NANDINA}

NANDINA DOMESTICA (Heavenly Bamboo) A most striking plant in fall and winter, when the normally green leaves turn a deep crimson. Mature plants have large clusters of brilliant scarlet berries which hang on well after Christmas. A beautiful upright growing shrub, doing well in either sun or shade. Particularly desirable when planted in front of green foliaged plants.

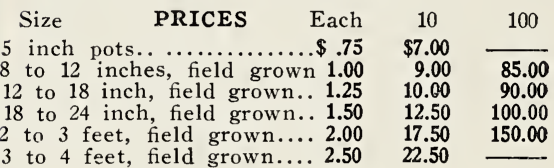

\section{JASMINE}

JASMINUM PRIMULINUM. A graceful drooping evergreen with dark green leaves. Produces large yellow flowers in early Spring.

\section{PRICES}

Size

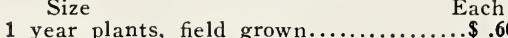

2 year plants, field grown............... 1.00

10

$\$ 5.00$

\section{LIGUSTRUM}

LIGUSTRUM OVALIFOLIUM VARIEGATA. An excellent strong growing shrub with variegated leaves. Grows to a height of 12 to 15 feet. Will stand severe pruning, however, and can be kept at any desired height.

\section{PRICES}

\section{Size}

Each 10

100

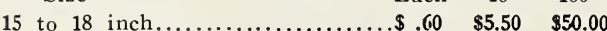

18 to 24 inch....................... $75 \quad 7.00 \quad 65.00$

LIGUSTRUM JAPONICUM. An excellent tall growing evergreen, especially suited for corners and for screening. Can be grown into a small tree. Has large, deep green leaves, white flowers in panicles which are followed by attractive purple berries.

\section{PRICES}

Each $10 \quad 100$

2 to 3 feet, bare root..........\$.50 $\$ 4.50 \$ \$ 40.00$

3 to 4 feet, bare root.......... $1.00 \quad 9.00 \quad 80.00$

4 to 5 feet, bare root............ $1.50 \quad 12.50 \quad 100.00$

5 to 6 feet, bare root............. $1.75 \quad 15.00 \quad 125.00$

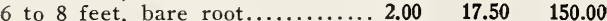

Balled and Burlapped, add 50 per cent to the above prices.

\section{ȦBELIA MOST SATISFACTORY HEDGE}

Abelia is probably the most satisfactory hedge for all purposes. It makes a very beautiful informal hedge. Used in this way it does not require much pruning-only enough to make the hedge grow bushy and compact. It may also be pruned to a formal hedge, trimmed to either a flat or rounded top. Whatever way used, its masses of pinkish-white blossoms will be a great source of pleasure throughout its long summer blooming period. See page 15 for prices.
We Are Members--

American Association of Nurserymen

Southern Nurserymen's Association

Georgia Association of Nurserymen

National Pecan Growers' Association

National Pecan Growers' Exchange

Georgia-Florida Pecan Growers' Association

National Home Planting Bureau 


\section{PHOTINIA}

PHOTINIA SERRULATA. A very attractive shrub or small tree. Especially attractive in the spring and in the fall; in the spring it produces white flowers in large corymbs; in the fall much of its foliage takes on varying hues of red. Desirable for foundation planting or for the shrub border.

\section{PRICES}

Size Each 10

2 to 3 feet.................... $\$ 1.00 \$ \$ 9.00$

3 to 4 feet...................... $1.50 \quad 12.50$

4 to 5 feet................. 2.00 17.50

\section{PITTOSPORUM}

PITTOSPORUM TOBIRA. This evergreen shrub can be sheared ta any desired shape. When allowed to grow informally it forms a very bushy, compact, widespread shrub. The small flowers are creamy in color and of delightful fragrance. This variety is un. excelled for massing and foundation plantings.

PRICES

Size Each $10 \quad 100$

10 to 12 inch.............. \$.75 $\$ 7.00 \$ \$ 65.00$

12 to 15 inch................ $1.00 \quad 9.00 \quad 80.00$

15 to 18 inch............... $1.50 \quad 12.50 \quad 100.00$

\section{TEA OLIVE}

OSMANTHUS FRAGRANS. A large growing shrub having glossy foliage and producing small white flowers, valuable for their delightful fragrance. Long blooming period. Attains a height of about 20 feet. Should have partial shade when starting.

\section{PRICES}

Size

5 inch pots, 18 to 24 inches............\$1.50

Each 10

\section{TEA PLANT}

THEA BOHEA. The leaves of this plant are used for making the tea of commerce. A beautiful low growing winter blooming shrub which produces attractive white flowers. Dark green foliage, dense, and stands shearing well.

\section{PRICES}

Size $\quad$ Each 10

15 to 18 inch, bushy................. \$1.25 $\$ 10.00$

\section{VIBURNUM}

VIBURNUM ODORATISSIMUM (Sweet Viburnum). An evergreen shrub succeeding all over the lower South. Leaves large and glossy green. Fragrant white flowers appear in the late Spring. Attains a height of 8 to 10 feet. Good in partial shade.

\section{PRICES}

15 to 18 inch, B.\&B................ $\$ 1.00 \$ 9.00$

18 to 24 inch, B.\&B................. $1.50 \quad 12.50$

VIBURNUM JAPONICUM (V. Macrophyllum). Recently introduced from California, this plant is proving very valuable in the lower South. Of about the same hardiness as V. Odoratissimum. Of dwarf growth, leaves thick, heavy, dark green. Very compact. Excellent for foundation planting. Maximum height about 6 feet.

Size

PRICES

Each

10

12 to 15 inch.

$\$ 1.00$

$\$ 9.00$

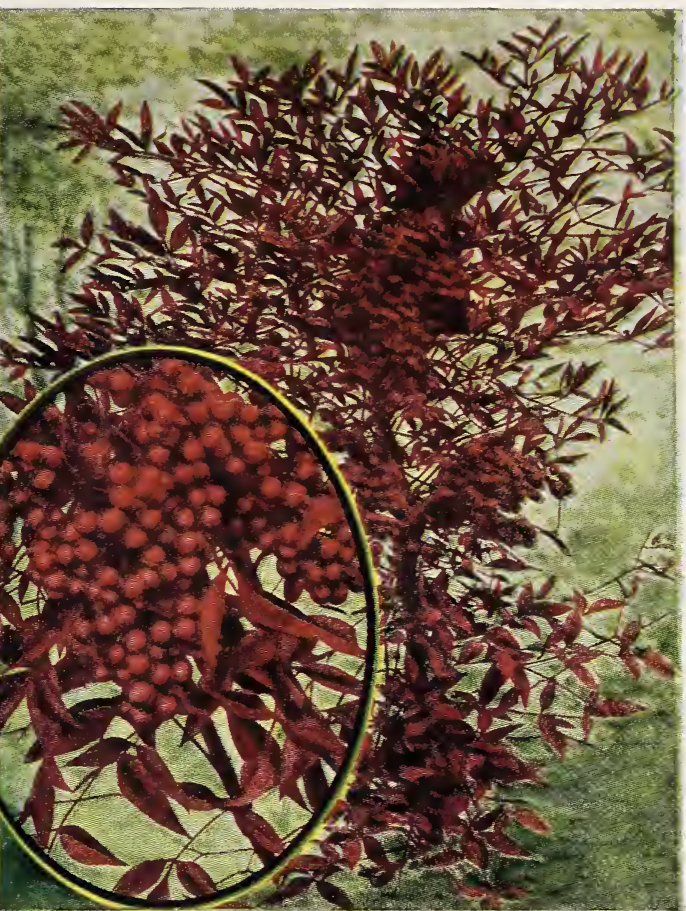

Nandina Domestica.

VIBURNUM SUSPENSUM (Sandankwa Viburnum). Of spreading habit, this shrub has large dark green leaves with ruffled edges. Fragrant creamcolored flowers borne in profusion. Stands shearing well and can be kept as low as desired, although its ultimate height is only about 8 to 10 feet.

Size

PRICES

10 to 12 inch, B.\&B..............\$1.00
Judge R, M. Mann, Little Rock, Ark."They have done unusually well. I have had a very small mortality in these trees, and have taken good care of them, and am very much pleased with them; in fact. I am recommending to all pecan growers in this State to purchase their trees from you, because I think you are better located for Arkansas conditions and furnish more reliable trees than can be obtained elsewhere.

Mr. H. D. Yawn, Milan, Ga.-"It is a pleasure to let you know about my trees; it was eight years ago that I saw your ad. in the Christian Index, and I bought 25 trees. My trees are the finest trees I ever saw anywhere. My trees started to bear the third year after planting. I bought 12 trees fro:n a tree agent. One of your trees is worth all the $12 \mathrm{I}$ bought from the agent." 


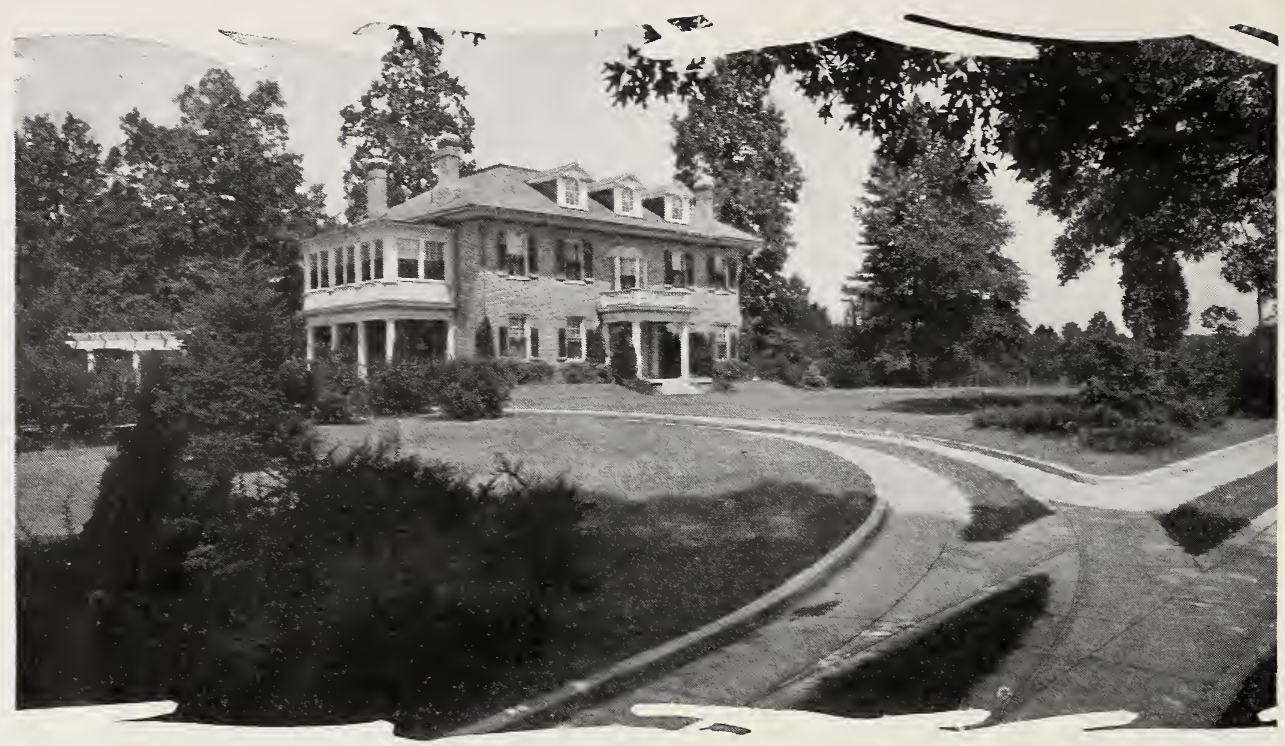

\section{CONIFEROUS EVERGREENS}

\section{ARBORVITAE}

AMERICAN ARBORVITAE (Thuya Occidentalis). An erect form of arborvitae, adapted to a wide range of soils and conditions. Does not burn out in the South like some varieties. Ultimate height, 15 to 20 feet.

\section{PRICES}

Size $\quad$ PRICES 10

10 to 12 inch........................ \$ .75 $\$ 7.00$

12 to 18 inch.......................... $1.25 \quad 10.00$

18 to 24 inch......................... $1.50 \quad 12.50$

BERCKMAN'S GOLDEN ARBORVITAE (Thuya Orientalis Aurea Nana). One of the best known and most desirable dwarf arborvitae. Compact and symmetrical. Leaves are deep green, with golden tinted tips.

$$
\text { PRICES }
$$

Size Each 10

10 to 12 inch, B.\&B................ $\$ 1.00 \$ \$ 9.00$

12 to 15 inch, B.\&B.................... $1.50 \quad 12.50$

15 to 18 inch, B.\&B....................

GLOBE ARBORVITAE (Biota Globosa). A dwarf arborvitae which gets its name from the fact that it grows in the shape of a globe. Dense dark green foliage which turns bronze in the winter. Desirable for foundation planting in front of other evergreens, and for pots or tubs.

\section{PRICES}

\section{Size}

10 to 12 inch spread.

18 to 24 inch spread...................... 3.00

10

25.00

ORIENTAL ARBORVITAE (Thuya Orientalis). Seedlings. Tall, loose growing types, growing to make large trees. Broad at the base, pyramidal. Beautiful dark green foliage. Will stand shearing well. Sometimes used for hedges, often for screening and windbreaks.

PYRAMIDAL ARBORVITAE (Thuya Orientalis Pyramidalis). Selected seedlings true to type.
Not so spreading as T. Orientalis. Probably the South's best coniferous evergreen. Blue green foliage; grows tall, stately.

\section{PRICES, ABOVE TWO VARIETIES}

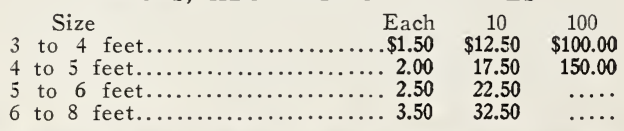

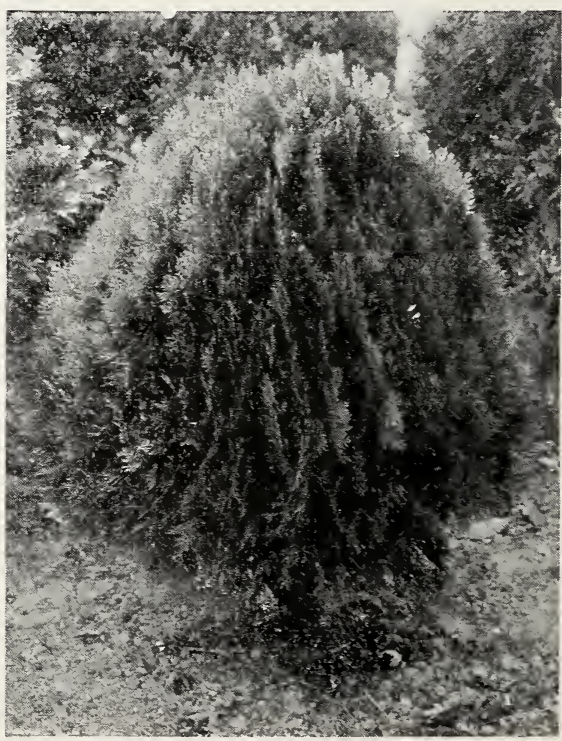

Berckman's Golden Arborvitae. 


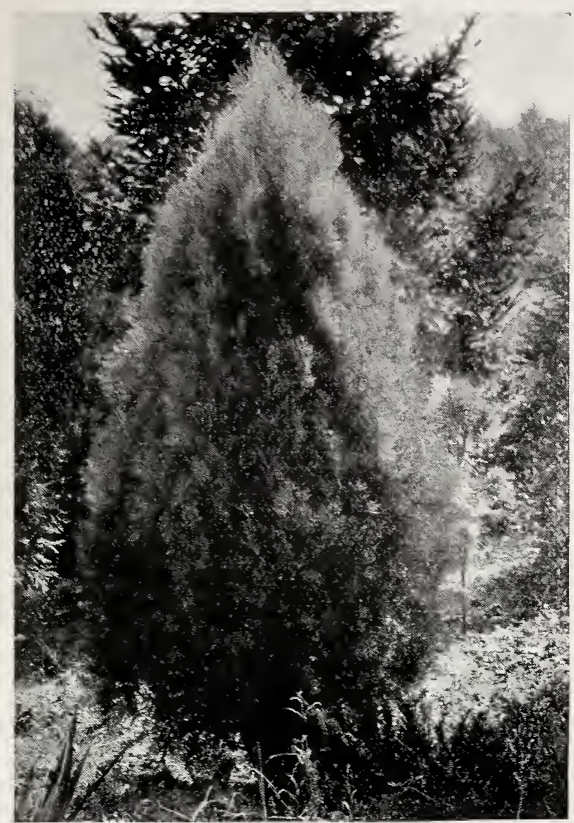

Oriental Arborvitae.

\section{CEDAR}

DEODAR CEDAR (Cedrus Deodara). A favorite wherever a tall stately specimen plant is wanted. Beautiful upright growing cedar with silvery bluegreen foliage. Very graceful. Unsurpassed for a specimen plant.

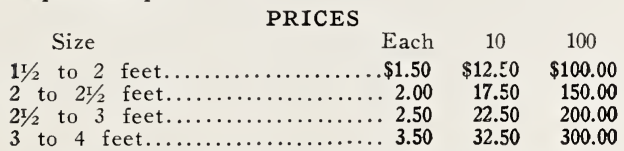

ATLAS CEDAR (Cedrus Atlantica). Foliage similar to Deodar Cedar but little shorter and stiffer. Not quite as fast a grower as Deodar. May be used in same way, however.

\section{PRICES}

Size Each 10

15 to 18 inch......................... \$1.00 $\$ 9.00$

18 to 24 inch......................... 1.50

\section{CYPRESS}

ARIZONA CYPRESS (Cupressus Sempervirens). A very attractive slender pyramidal tree of medium growth; foliage pale green. Very attractive.

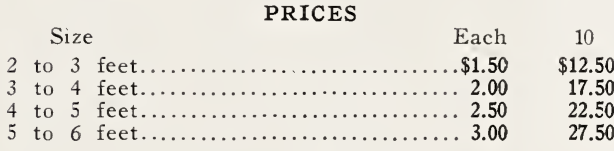

\section{ITALIAN CYPRESS}

CUPRESSUS SEMPERVIRENS PYRAMIDALIS. Very attractive, columnar growth. Reaches a height of 40 to 50 feet, but never spreads very much at the bottom. Excellent for planting in front of columns, pillars, etc.

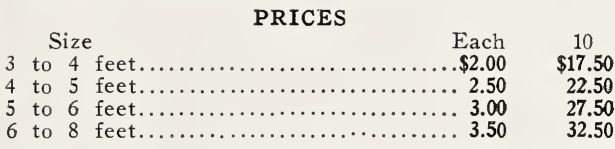

"How To Plant the Home Grounds" A new booklet, edited by "Chinese" (E. H.) Wilson, famous plant explorer and horticulturist of the Arnold Arboretum, is ready for distribution to our customers desiring it. The booklet pictures and describes the modern trend in beautifying home grounds, and is an excellent guide to modern planters.

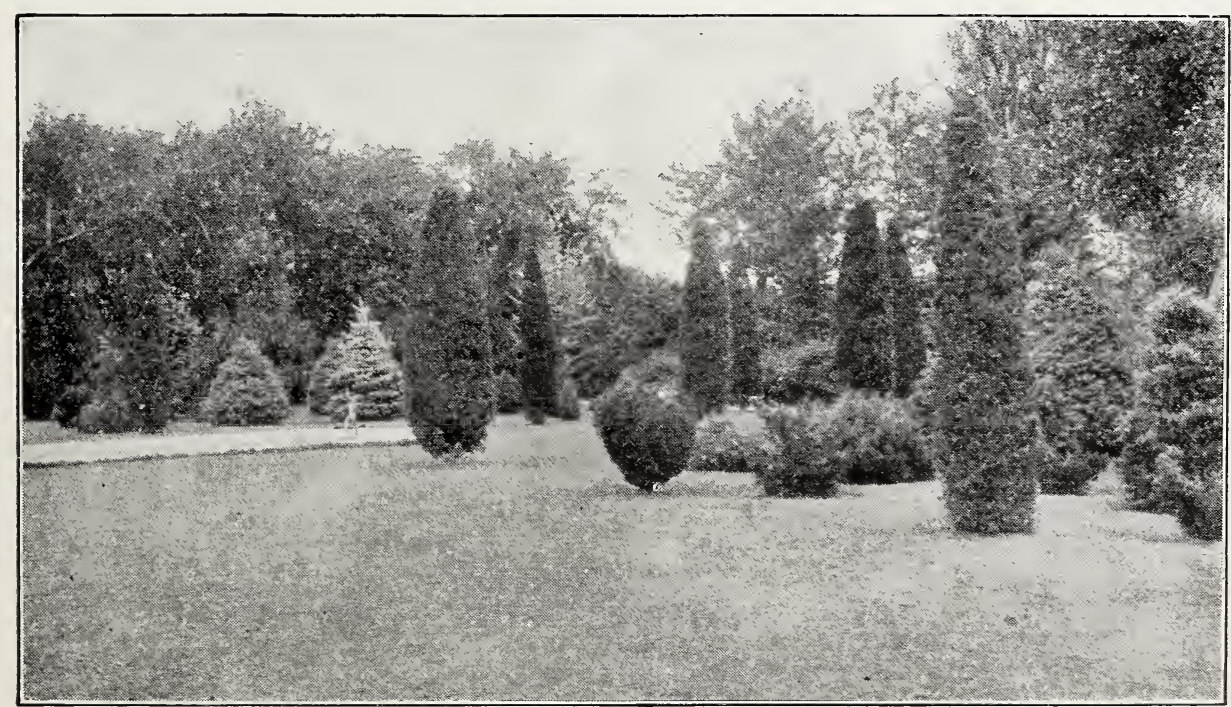




\section{JUNIPERS}

CHINESE JUNIPERS (Juniperus Chinensis). An attractive many branched pyramidal shrub, sometimes columnar in effect. Attractive green foliage with a touch of blue. Will thrive in almost any well drained soil.

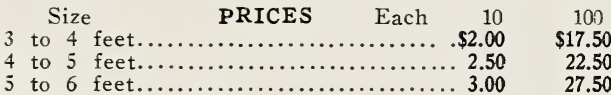

ENGLISH JUNIPER (Juniperus Communis). One of the best junipers; hardy, erect; columnar in some forms. Foliage very attractive.

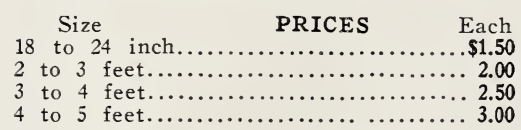

PFITZER JUNIPER (Juniperus Chinensis Pfitzeriana). An excellent new Juniper of spreading habit. Very attractive grey-green foliage. Valuable for foundation planting where a low spreading plant is needed, and for planting in front of other conifers.

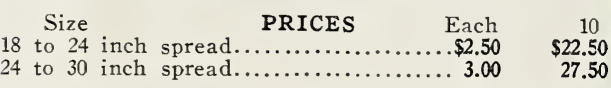

VIRGINIA RED CEDAR (Juniperus Virginiana) The beautiful native Redcedar of Virginia. An excellent shrub for screen or windbreak, or as a specimen tree. Grows to a great height. Tall, stately. Foliage grey-green.

\section{PRICES}

Same as Chinese Juniper, up to 5 -foot grade.

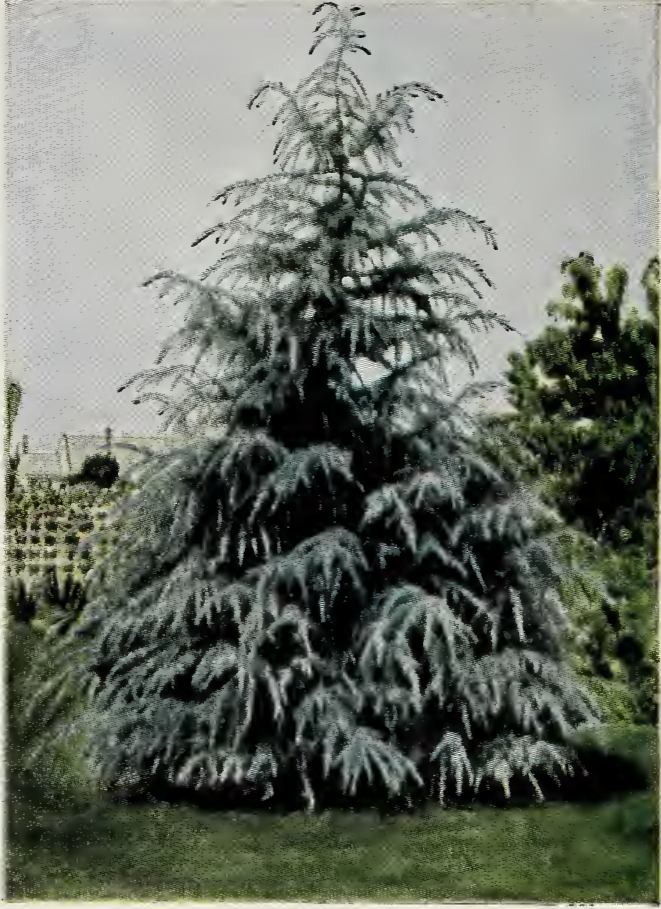

Cedrus Deodara.

\section{LIVING CHRISTMAS TREE}

Perhaps no idea for the Christmas season has met with such widespread approval as has the idea of a living Christmas tree. Each year sees, around Christmas time, more and more specimen trees in the yard lighted up with electric light globes of many colors to make up a very striking effect. How much nicer to have the living Christmas tree out in the yard where the passerby as well as your own family can enjoy it, rather than to go to the woods and cut down and destroy a beautiful tree for just a few days pleasure inside the house. Plant now so that you may have your own living Christmas tree from now on. Cedrus Deodara is an excellent tree for this purpose.
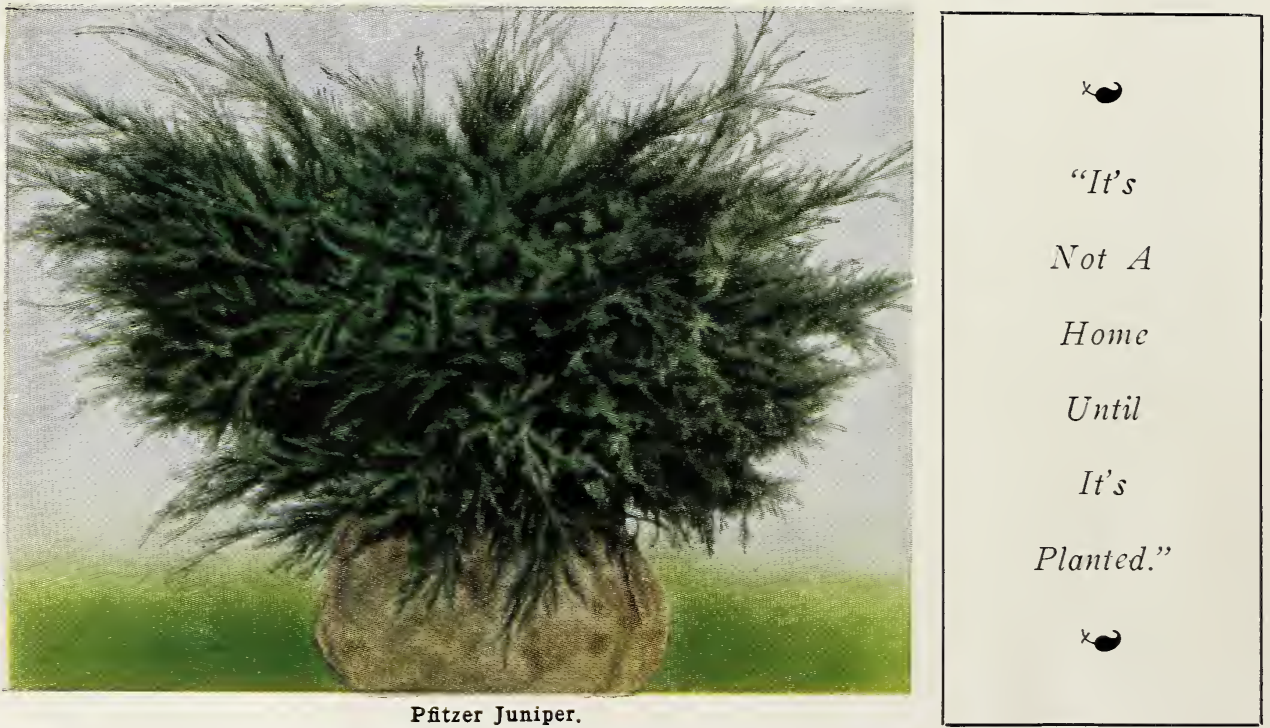

Pfitzer Juniper. 


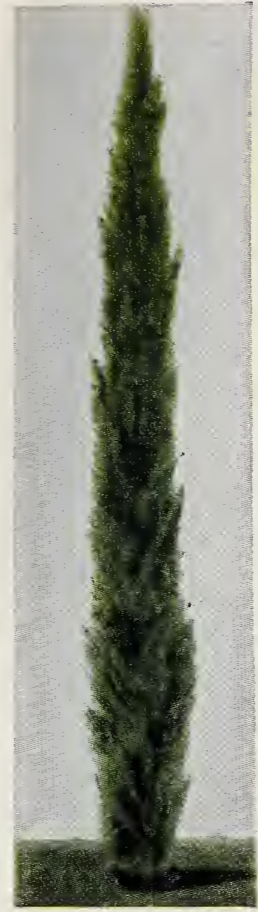

Italian Cypress.

\section{PODOCARPUS}

PODOCARPUS SINENSIS. An attractive introduction from Japan. One of the largest of all the conifers. Foliage deep green. Grows to a height of 40 to 50 feet. Our plants are not allowed to send up but one shoot from the ground, and are staked to make attractive specimens.

\section{PRICES}

Size

24 to 30 inch, B. \&B

Each $\$ 1.50$

$\$ 12.50$

\section{RETINOSPORA}

CHAMAECYPARIS PLUMOSA AUREA (Golden Plumed Retinospora). One of the best and most desirab!e Chamaecyparis. Vigorous grower, tall and stately. Retains its golden green color. Very desirable.

\section{PRICES}

\section{Size}

12 to 15 inch, B.\&B........ \$1.25

15 to 18 inch, B.\&B.......... 1.50

18 to 24 inch, B. \& B......... 1.75

2 to 3 feet, B.\&B............ 2.00

3 to 4 feet, B.\&B............ 2.50

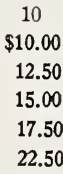

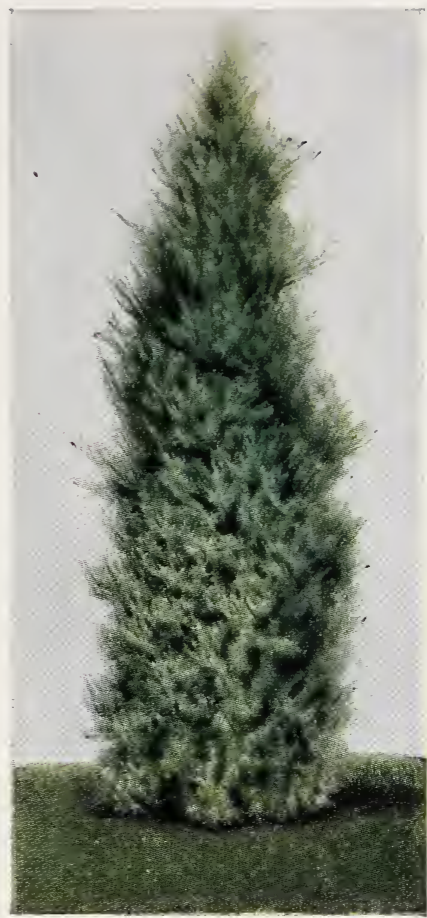

Arizona Cypress.

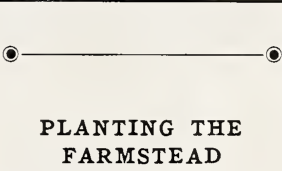

Beautifying the grounds about the farm home and planting at least a small home orchard are two means of increasing the value of every acre of land on the farm. Trees and shrubs are the only things in the world that do not depreciate with use--the longer you keep them and the older they get, the more valuable they are.

Investigations by one of the State Experiment Stations have definitely proven that the proper planting around the farm homestead is one of the most profitable investments a farmer can make.

(c) 


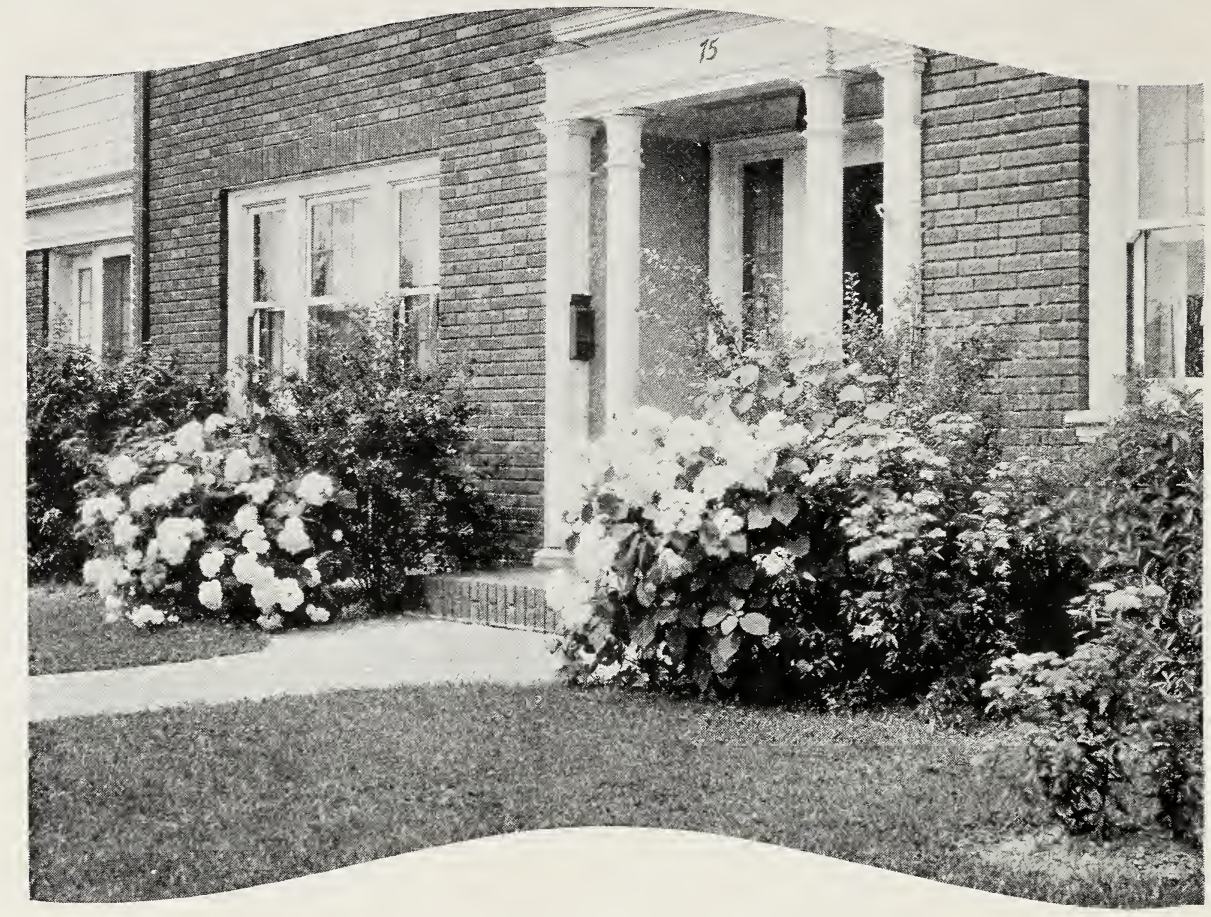

\section{ORNAMENTAL SHRUBS}

$P$ ROBABLY no single group of plants makes as much show or gives as much pleasure for the amount of money invested than do the plants of the deciduous group. To them in most instances must we look for the color, the variety, the striking effects in the garden. They lend the finishing touches to the landscape, giving it the charm of hominess and adding symmetry and beauty.

Wherever shrubbery can be used, there is some type of flowering shrub whch will fit the particular purpose. With careful selection as to the height, ornamental shrubs will soften the line of foundations, walls and borders. One should be careful not to get tall growing plants in front of low-growing ones.

Probably the most pleasing, the most tasteful planting of ornamental flowering shrubs is in the back yard-which modern gardeners have transformed into an outdoor living room. Here you can use the tall growing sorts as screens to hide unsightly views and to make your outdoor living room really private. Here one may indulge in the riot of color possible with flowering plants without subjecting one's planting to the harsh criticisms of the passersby on the street.

Some of the plants listed bloom in early Spring; others later in the season, so that by wise selection one may have a succession of blooms throughout the season.

\section{ALTHEA}

ALTHEA (Hybiscus Syriacus). An excellent freeblooming shrub, upright, which blooms over a long period of late summer. Ultimate height, 8 to 10 feet. Colors: Double White, Double Purple.

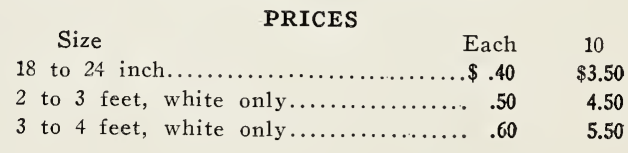

\section{BEAUTYBERRY}

AMERICAN (French Mulberry) (Callicarpa Americana). A very attractive native plant desirable for its masses of purple berries which appear all along the stem of the plant. Berries stay on for several months in late summer and early fall. Birds are very fond of the fruit.

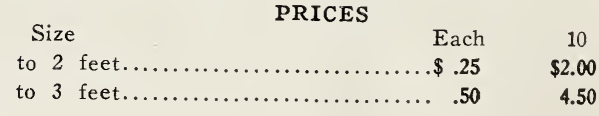




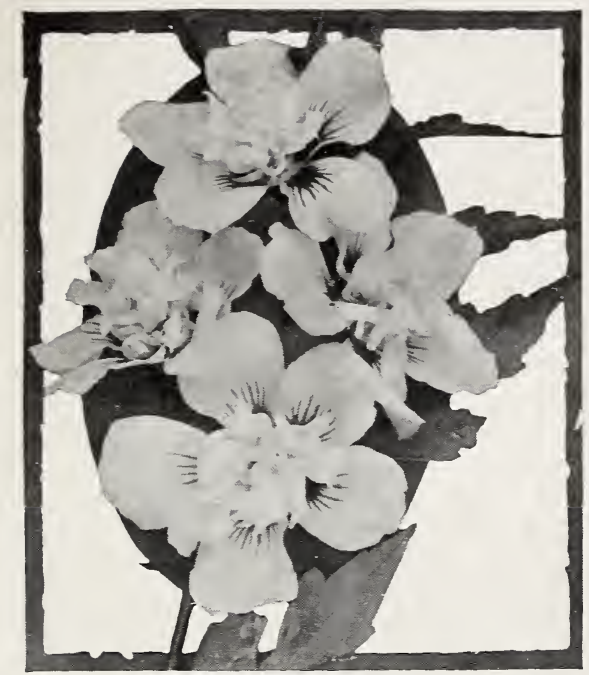

Althea.

\section{CRAPE MYRTLE}

CRAPE MYRTLE (Lagerstroemia Indica). An old favorite in the South, too well known to need description, and yet not used as much as some of the improved varieties deserve to be.

\section{PRICES}

Purple, Watermelon Pink.

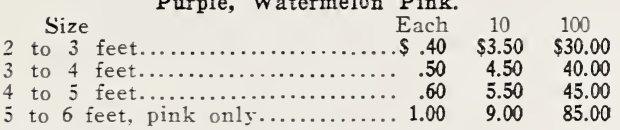

Our RED CRAPE MYRTLE is an especially fine dwarf strain, having unusually large racemes of deep red flowers.

\section{PRICES}

\section{Red Crape Myrile}

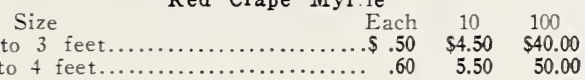

\section{DEUTZIA}

DEUTZIA (Pride of Rochester). One of the most desirable shrubs. Their hardiness, luxuriant foliage, and profusion of attractive flowers render them deservedly among the most popular of flowering shrubs. Ther are extremely floriferous and ornamental and make possible many striking effects in garden or border plantings.

$$
\text { Size PRICES }
$$

\section{PRICES}

2 to 3 feet.......................... $\$ .40$

10

$\$ 3.50$

3 to 4 feet.

4 to 5 feet...........................60

4.00
5.50

\section{PEARL BUSH}

PEARL BUSH (Exochorda Grandifera). One of the most striking of Spring flowering shrubs. In the early Spring and before the leaves appear, the bush is covered with white pearl-shaped blossoms. Best used in groups. 6 to 8 feet.

$$
\text { Size }
$$$$
\text { PRICES }
$$

\section{GOLDEN BELL}

FORSYTHIA. An excellent early Spring flowering shrub producing very attractive golden-yellow flowers. Hardy and of easy culture. 8 to 10 feet.

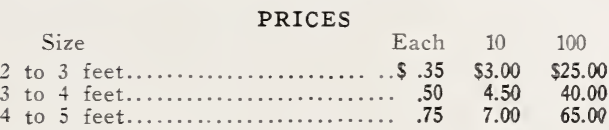

\section{BUSH HONEYSUCKLE}

LONICERA FRAGRANTISSIMA. Probably the most desirable bush honeysuckle. Attractive deep green foliage, some of which is retained throughout the winter in the latitude of Cairo. Small inconspicuous white flowers which are very fragrant.

LONICERA MORROWI (Morrow Honeysuckle). Produces in April a mass of white flowers, which are followed by very attractive red berries.

LONICERA TARTARICA (Tartarian Honeysuckle). Similar to Morrow Honeysuckle, except that blossoms are pink. Blooms in April, followed by red berries.

PRICES

Bush Honeysuckle.

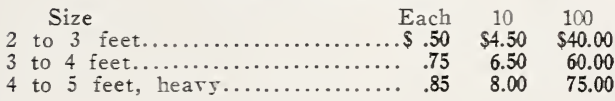

\section{BUTTERFLY BUSH}

BUDDLEA. Flowers of deep shade of violet; blooms from June until frost. Excellent for massing; attracts butterflies.

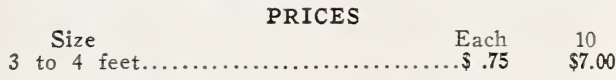

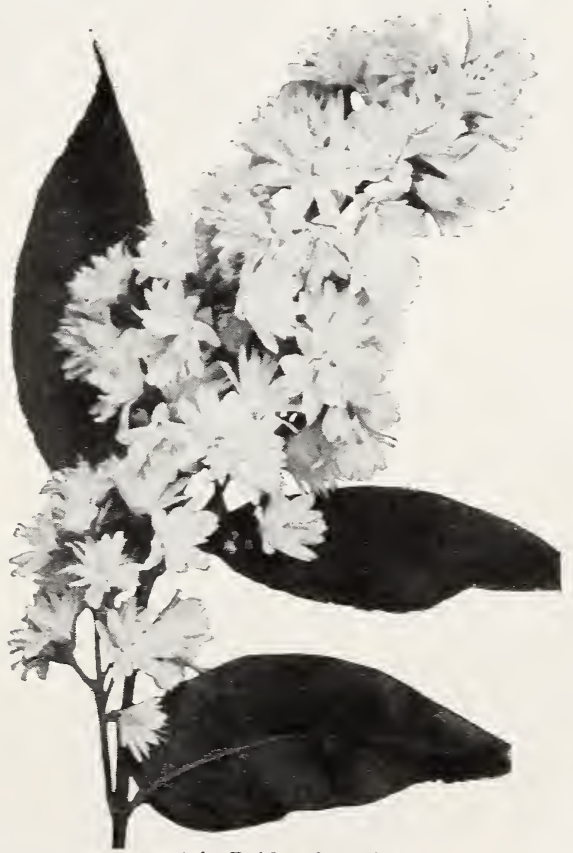

Deutzia Pride of Rochester. 


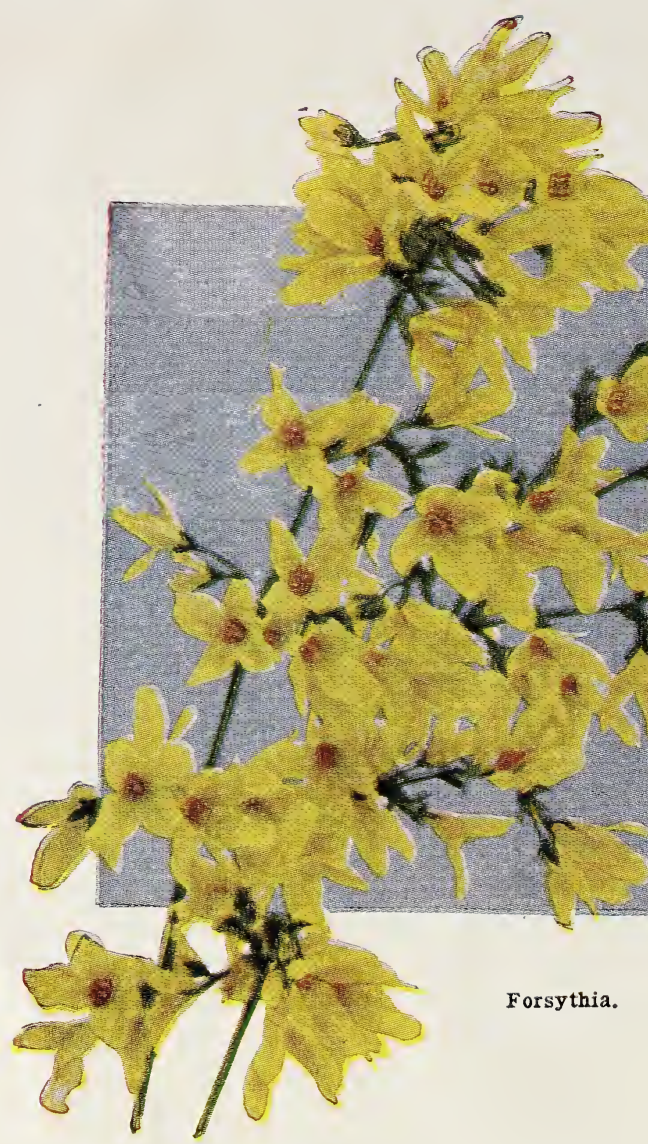

\section{MOCK ORANGE}

PHILADELPHUS CORONORIUS (Syringa or Mock Orange). Fine old shrub, with white blossoms similar to orange blossoms, borne early in the Spring. Ultimate height, 8 to 10 feet.

$$
\begin{array}{llll}
\text { Size } & \text { PRICES Each } 10 & 100
\end{array}
$$

2 to 3 feet...................... $.35 \quad \$ 3.00 \quad \$ 25.00$

3 to 4 feet...................... $.50 \quad 4.50 \quad 40.00$

4 to 5 feet........................ $75 \quad 7.00 \quad 65.00$

\section{FLOWERING PEACH}

DOUBLE RED FLOWERING PEACH. Excellent for use in the shrub border.

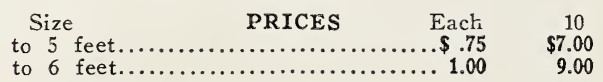

\section{ORANGE, HARDY}

ORANGE, HARDY (Citrus Trifoliata). Used commercially in the lower South as the root stock for Satsuma oranges. It has ornamental value in the shrub border or as a hedge. The leaves are dark, lustrous green; blossoms very fragrant, similar to other orange blossoms; fruit small, attractive, turning a deep yellow early in September. Fruit not edible. Hardy in the North.

$$
\text { Size }
$$

PRICES

Each

1 year plants $10 \quad 100$

\section{FLOWERING POMEGRANATE}

PUNICA GRANATUM RUBRA. Valuable summer flowering, tall growing shrub. Perfectly hardy in the South. Very profuse bloomer early in May and throughout the summer. Foliage is bright green and flowers a beautiful red.

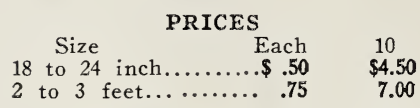

\section{FLOWERING QUINCE}

CYDONIA JAPONICA. A most excellent flowering shrub for the lower South, due to the fact that it flowers during the late winter and early spring, at a time when blossoms are scarce. Blossoms deep red, appearing all up and down the stem. Hardy. Ultimate height, 3 to 4 feet.

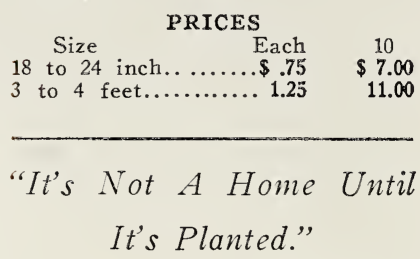

SPIRAEA

SPIRAEA ANTHONY WATERER. A very free flowering shrub growing to a height of about 2 feet. The branches are held upright and the foliage is bright green with variegations of yellow. Bright crimson flowers are borne in dense corymbs throughout the summer and fall. This is a very

\begin{tabular}{|c|c|c|c|}
\hline \multicolumn{4}{|c|}{ PRICES } \\
\hline Size & Each & 10 & 100 \\
\hline 10 to 12 inch. & $\ldots \ldots \$ .35$ & $\$ 3.00$ & $\$ 25.00$ \\
\hline 12 to $18 \mathrm{inch}$. & .... .50 & 4.50 & 40.00 \\
\hline 18 to 24 inch. & .75 & 7.00 & 65.00 \\
\hline 2 to 3 feet... & $\ldots \ldots \ldots \ldots \ldots 1.00$ & 9.00 & 85.00 \\
\hline
\end{tabular}
desirable shrub for the border.

SPIRAEA VAN HOUTTEX. The well-known bridal wreath. Widely grown favorite with dense foliage. White blooms in early Spring. Leaves persistent in Fall.

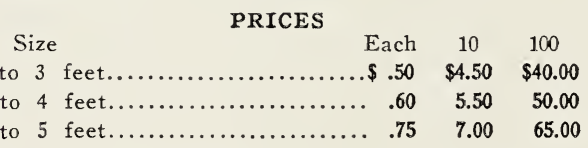

SPIRAEA THUNBERGI. A low, bushy plant with very small leaves and star-like flowers in such profusion that in early Spring the plant looks like a mass of snow. In the Fall the leaves color beautifully. Ideal for a low ornamental hedge or border.

$\begin{array}{lllll} & \text { PRICES } & & & \\ & & \text { Each } & 10 & 100\end{array}$

12 to 18 inch....................\$ $.50 \quad \$ 4.50 \$ 40.00$

18 to 24 inch.....................75 $7.00 \quad 65.00$

2 to 3 feet.................... $1.00 \quad 9.00 \quad 85.00$

3 to 4 feet..................... $1.25 \quad 11.00 \quad 100.00$ 


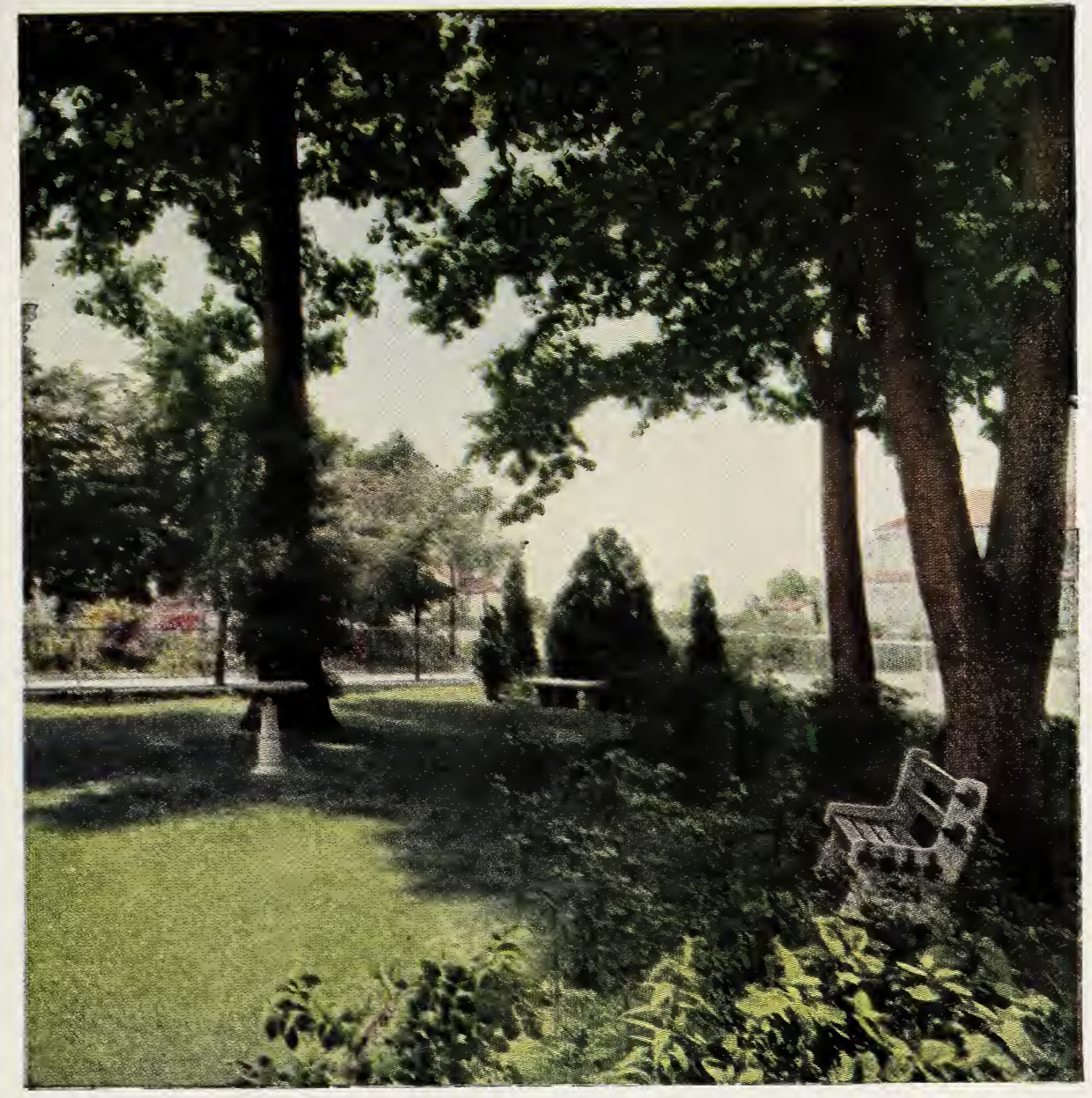

\section{Landscape Service}

We are very glad to be able to offer to our clients the services of our men experienced in planning and designing plantings for the small home.

Send us the dimensions of your grounds, the outside measurements of the house, the location of fences, trees and other permanent objects (these can be best shown by a rough sketch of the building and grounds), and we shall be glad to make you a drawing suggesting arrangement of landscape and the proper plants to use in each location. If possible send a small photograph of the building.

We require a deposit of $\$ 10.00$ before starting the sketch, the money to be credited to your account toward the purchasing of nursery stock for the planting. Should you not make the planting, the money will go to us to defray the expenses of the drawing.

Here is an excellent opportunity to have a real set of landscape plans drawn for your particular lot without the least additional cost to you. Hadn't you rather have your foundation planting, your entrance walks and drives, your rose garden and your outdoor living room planned by experienced landscape men, BEFORE YOU SET A SINGLE PLANT, than to plant haphazardly, without any idea how the final result will look? And remember, this service costs you nothing--you simply pay for the plants themselves.

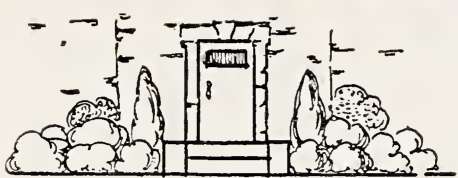

- ERONT ELEVATION。

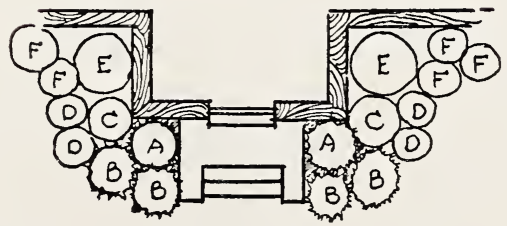

- DLAN.

Key No.

A 2 Pyramidal Arborvitae, 3-4 ft.

B 4 Spiraea A. W. $10-12$ in.

C 2 Spirea Vanhoutte, 2-3 ft.

D 4 Cydonia Japonica, 18-24 in

E 2 Photinia Serrulata, 2-3 ft.

F 3 Spirea Thunbergi, 12-18 in.

Above planting-Medium plants, regular price, $\$ 12.40$. Special Foundation planting price, $\$ 11.00$. 


\section{VINES}

Viues are a very interesting part of the wellplanted landscape. They have many uses and lend charm and beauty wherever used.

Perennial vines after they are once established, grow more vigorous each year. Woody vines, such as Wisteria and Fig Vine, grow to be quite old and often cover a large surface. For screening unsightly objects, for softening the lines of entrances and for covering pergolas in the garden, vines are almost indispensible.

CORAL VINE (Antignon Leptopus). Often called Mexican Rose. A perennial vine which blooms freely from June until fall. Blossoms a very delicate pink, produced in racemes. A very desirable vine for the South. Fast grower.

2 year, heavy........................ Each

ClIMBING FIG (Ficus Pumila, sometimes catalogued $F$. repens). A very attractive climbing evergreen vine with small lustrous green leaves; clings very closely to any surface it climbs on. Excellent for use on chimneys or brick buildings. Hardy along the Gulf Coast south of the latitude of Montgomery, Alabama.

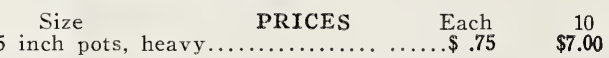

KODZU (Pueraria Thumbergiana). An exceedingly fast growing vine. Suitable where one requires a vine for very quick shade; difficult, however, to keep from spreading. Best known and used most extensively as a hay crop. (See page 11.)

$\begin{array}{ccccc}\text { Size } & \text { PRICES } & \text { Each } & 10 & 1.000 \\ \text { Roots } & \ldots \ldots \ldots \ldots \ldots \ldots \ldots \ldots \ldots \ldots & \$ .15 & \$ 1.00 & \$ 15.00\end{array}$

\section{YELLOW JESSAMINE}

CAROLINA YELLOW JESSAMINE (Gelsemium Sempervirens). Hardy in the Southeastern states. Well known woody twiner whose brilliant, tubular, yellow flowers are one of the first indications of the coming of Spring. Glossy evergreen foliage; excellent for fences and for ground-cover.

$\begin{array}{cccc}\text { Size } & \text { PRICES } & \text { Each } & 10 \\ \text { Open ground } & \text { plants.................. } \$ .35 & \$ 3.00\end{array}$

\section{TRUMPET CREEPER}

BIGNONIA RADICANS (Tecoma Smithi). Vigorous evergreen vine producing in early April a large number of trumpet shaped orange-red blossoms about two inches across. Hardy.

$\begin{array}{rcccc} & \text { Size } & \text { PRICES } & \text { Each } & 10 \\ 2 & \text { year, heavy } & \ldots \ldots \ldots \ldots \ldots \ldots \ldots \ldots \ldots & \$ .75 & \$ 7.00\end{array}$

\section{WISTERIA}

WISTERIA SINENSIS (Chinese Wisteria). Well known and greatly admired in the South; produces great racemes of purple flowers in April.

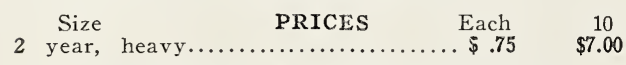

\section{TRUMPET HONEYSUCKLE}

LONICERA SEMPERVIRENS. Hardy. The native climbing honeysuckle. Broad attractive green leaves; Howers tubular, pink to scar'et color.

\begin{tabular}{cccc} 
Size & \multicolumn{1}{c}{ PRICES } & Each & 10 \\
Strong plants & $\ldots \ldots \ldots \ldots \ldots \ldots \ldots \ldots \ldots \ldots . .35$ & $\$ 3.00$
\end{tabular}

\section{PALMS}

cocos AUSTRALIS (Hardy Cocos). Of the few palms which ever have a chance of surviving the winters of South Georgia and Alabama-even Northern Florida-the hardy Cocos Australis is outstanding as the most satisfactory. A very beautiful hardy palm with greyish-green, curved leaves.

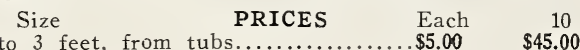

PHOENIX, DATE PALM (Phoenix canariensis). "Ornamental Date Palm." Canary Isles. $60 \mathrm{ft}$. It thrives under all sorts of conditions, is quite hardy, and grows very rapid!y. Its dense, immense crown of beautifully curving leaves, each 15 feet long and of a very pleasing dark green color, and its stately and rapid growth, combine to make this species an ideal palm for street, park and lawn.

Size PRICES Each 10

2 to 3 feet, B\&B................ \$3.00 $\$ 27.50$

3 to 4 feet, $B \& B \ldots \ldots \ldots \ldots \ldots \ldots \ldots \ldots \ldots .00, \quad 37.50$

4 to 5 feet, B\&B................... $7.00 \quad 67.50$

\section{GRASSES}

SNAKE'S BEARD (Ophiopogon Japonicus). A dwarf growing grass that is becoming quite popular in the lower South for edging walks and beds, and for ground cover in shady situations. Maximum height, 8 to 10 inches.

\section{PRICES}

$\begin{array}{crrc}\text { Size } & \text { Each } & 10 & 100 \\ \text { Small divisions } & \ldots \ldots \ldots \ldots \ldots \ldots .20 & \$ 1.75 & \$ 15.00\end{array}$

OPHIOPOGON JABURAN (Liriope Graminifolia). Similar to O. Japonicus but with broader leaves; produces lavender flowers on long spikes which are very attractive. Used for same purposes as $O$. Japonicus.

\section{PRICES}

Size Each $10 \quad 100$

Small divisions...............\$.25 \$2.25 $\$ 20.00$

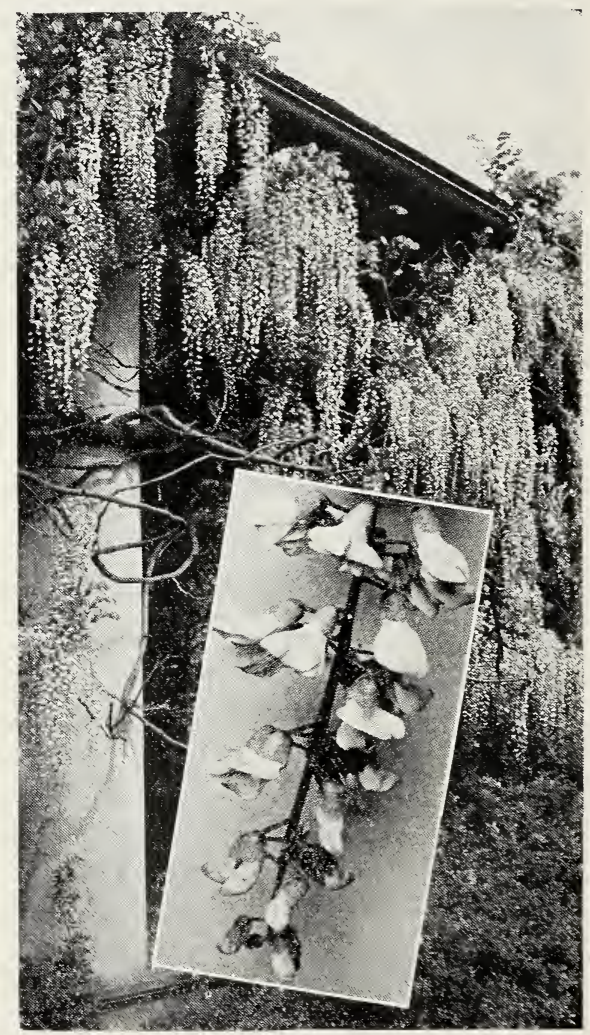

Wisteria. 


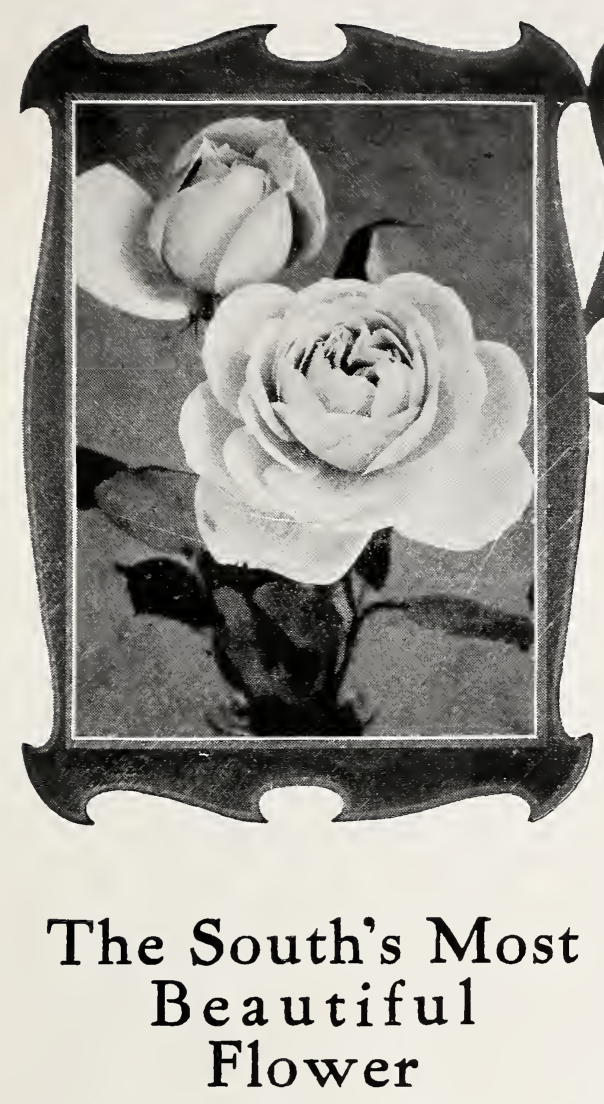

$S^{2}$ OMEWHERE in every garden, on every home-grounds, there is a place for roses - the favorite of all. Through the generations these fragrant flowers have delighted young and old-symbolizing for all the romance and beauty of yesterday, today and tomorrow.

The versatility and numerous varieties of roses make it possible for you to grow just the rose you love. The climbing roses may be chosen to arch the trellis over the garden walk or to add beauty and charm to the open veranda, the wall or fence. Bush roses may be grown everywhere and anywhere about the garden and home-grounds, lending an atmosphere of cheer and graceful beauty that only roses can give.

The rose was a June flower in grandmother's day; now after years of experimentation, careful breeding and cultivation, these exquisite flowers brighten the entire summer with their profusion of color, their fragrance and charm. Throughout the growing season, roses may be had in a succession of bloom in shades to fascinate everyone.

\section{HOW TO GROW ROSES}

SOIL: Roses can be grown in almost any fertile, well-drained soil, but the best roses

\section{( \\ oses the Garden or the}

are grown in rich loamy soil which has been especially prepared by being drained and fertilized. If the soil is thin, it is advantageous to add some heavier soils.

Plant roses in sunny locations with special care that there are no large tree roots in the soil to interfere with the growth of the plants. Good results will come only when the ground is kept free from weeds. As to fertilizers, well rotted cow manure, leaves or leaf mold are beneficial. Break up the ground around the plants by frequently stirring the soil, taking care not to injure the roots. Protect the plants in winter by mounding up the soil around them.

PLANTING: Place the rose in a hole 6 inches wider than the spread of the roots and about 1 inch deeper than the soil mark on the plant. Budded roses should be planted deeper-the budded portion being set two or three inches below the level. Half fill the hole with earth and then water profusely. Allow this to seep away and complete the filling process. Mound and pack the earth firmly around the bush.

PRUNING: Pruning of roses when planting differs according to type of rose planted. Cut back the weaker growth. When planting in the Fall the dormant rose should be cut back about one-half its length. Prune again in the spring leaving two or three stems with four or five buds on each stem. Do not prune too early-not before January 1 . For the older roses, cut away about two-thirds of the past year's growth, ridding the plant of all weak shoots and decayed wood. Vigorous varieties should be pruned less.

SPRAYING: Aphis may be removed by turning a strong spray of water on the plant. Blackleaf 40 and strong soap suds in solution-1 oz. Blackleaf and $1 \mathrm{lb}$. laundry soap in 8 gallons of water-will handle this pest as well as thrips. Blackspot and mildew may be taken care of with Bordeaux mixture.

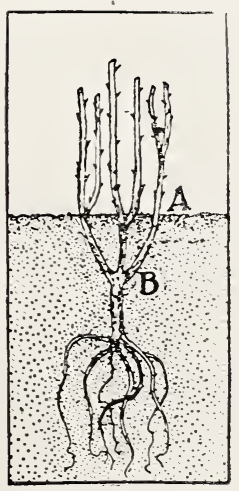




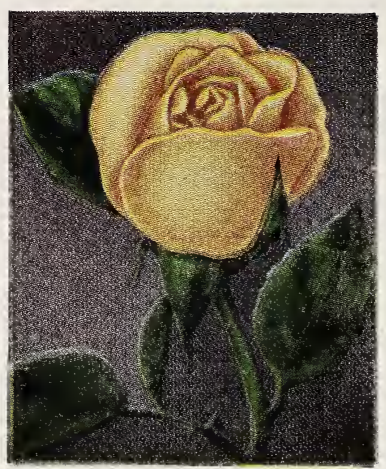

Lady Hillingdon.

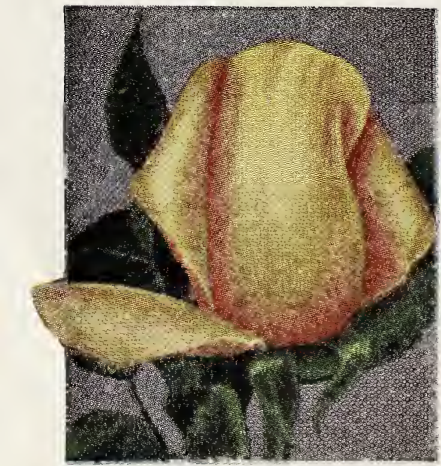

Luxembourg.

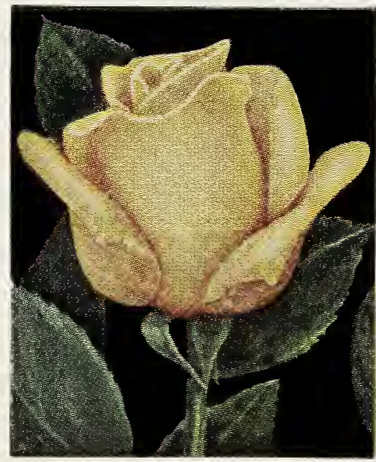

Sunburst.

\section{WHITE ROSES}

WHITE COCHET. The family traits and beauty of the Coclet family are preserved in this rose; white with edges of petals tipped rose. Among the best white tea roses.

WHITE AMERICAN BEAUTX (Frau Karl Druschki) H.P. The regal "White American Beauty." The distinctive form and expression of its bud, half opened state, and maturity, are a three-fold revelation of exquisite charm and beauty. Large flowers of waxy paper white in June; yielding their final outburst with the first snow of fall.

KAISERIN AUGUSTA VICTORIA. T. Another excellent pure white rose which does especially well in the lower South. Free and regular bloomer; large blossoms.

WHITE KILLARNEY. Sport of the well-known Killarney. Very beautiful in bud; quite satisfactory rose.

\section{PRICES-ROSES, ALC VARIETIES}

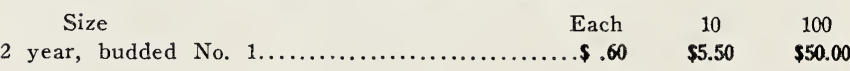

\section{YELLOW ROSES}

We are listing here the best Yellow Roses for Southern gardens. Although there are a great many varieties of yellow roses, the number which will succeed in the South is quite limited. We therefore are listing only those which we know absolutely will give satisfaction.

LADY HILLINGDON. T. Apricot-yellow, especially beautiful in the bud; free bloomer, strong grower.

LUXEMBOURG. H.T. One of the very best yellows of the new hybrid teas. A deep golden yellow, very attractive both in its pointed bud and as an open flower.

MARECHAL NEII. Climber. An old favorite which needs no description.

SUNBURST. H.T. A most excellent yellow rose; blossom deep yellow with shadings of orange; buds long and pointed. One of the most striking roses suitable for Southern gardens.

\section{PRICES-ROSES, ALL VARIETIES}

$\begin{array}{lccc}\text { Size } & \text { Each } & 10 & 100\end{array}$

\section{Special Offer No. 2}

Six vigorous, healthy No. 1 Climbing Roses selected from the following varieties:

$\begin{array}{ll}\text { Paul's Scarlet Climber } & \text { Reine Marie Henriette } \\ \text { Marechal Neil } & \text { American Pillar Rose } \\ \text { Devoniensis } & \text { Silver Moon } \\ \text { Climbing Pink Cochet } & \text { Reve d'Or }\end{array}$

All Two-Year Plants

Six Climbing Roses, 2 year, for only . . \$2.50 


\section{PINK ROSES}

MADAME LAMBARD. T. Rose tint shading to salmon and bronze. A free bloomer with strong spreading habit.

ANTOINNE REVOIR. H.T. A vigorous grower and bloomer, and one of the most desirable light shell-pink roses.

MRS. CHARLES BELL. H.T. Soft shell pink with a salmon back. ground. It retains its full globular shape an unusually long period.

PINK RADIANCE. H.T. Extra hardy, vigorous and prolific; one of the best all-around Garden Roses. Its color is a beautiful blending of carmine-rose with shades of opal and copper.

DUCHESS OF SUTHERLAND. H.P. Deep pink flower shading into a rich lemon color. Plant upright and sturdy. Buds long pointed, and blooms very large.

PAUL NEYRON. H.P. One of the best hardy roses ever grown. It blooms intermittently from June to November, on iong, smooth, thornless stems, furnishing a vast quantity of uniform flowers 4 to 6 inches across. Color a bright ruddy pink. Particularly good in Autumn.

MAMAN COCHET. Mother of many noted favorites, establishing a type as well known and appreciated as any group in the Tea section. The color is rich, clear pink daintily flushed with silvery rose.

CIIMBING PINK COCHET. A strong climber. Flowers are color and size of bush Maman Cochet.

PINK KILLARNEY. H.T. Brilliant silvery pink, very long and graceful bud.

AMERICAN PILLAR. Climber. H.W. Large single blossoms, rosypink to carmine, with bright yellow stamens. Blossoms appear in great clusters. Unusually vigorous grower.

\section{PRICES-ROSES, ALL VARIETIES}

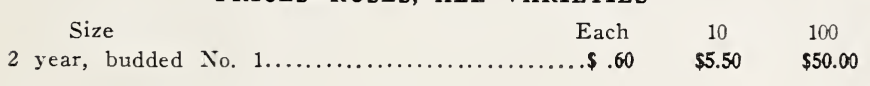

\section{RED ROSES}

PAPA GANTIER. T. A bright crimson rose with sturdy stems. It is a very continuous bloomer; the foliage is vigorous and enduring, and the flowers semi-double.

RED RADIANCE. H.T. The globular, heavy-stemmed "Radiance" duplicated in all respects except color; this sport form being a brilliant crimson.

REINE MARIE HENRIETtE. Climber. ("Red Gloire de Dijon".) Fragrant cherry-red flowers. The plant is vigorous and has a strcng climbing habit of growth. Super-abundant bloom early in the season.

ETOILE DE FRANCE. H.T. Blossoms a dark, velvety red, good shape and substance. The best deep red for the lower South.

LOUIS PHILLIPPE. (Bengal.) Especially adapted for use as a hedge, this lovely rose has small deep crimson blossoms in great profusion in the Spring and Fall.

\section{PRICES-ROSES, ALL VARIETIES}

Size Each

2 year, budded No. 1 . . \$.60 10 $\$ 5.50$

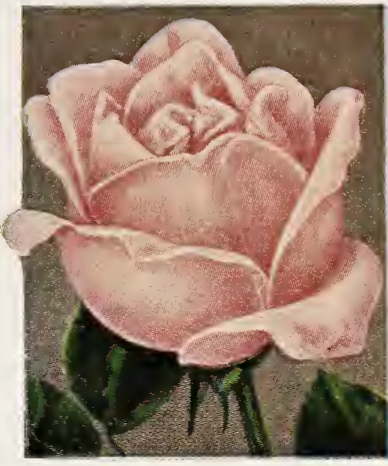

Mrs. Charles Bell.

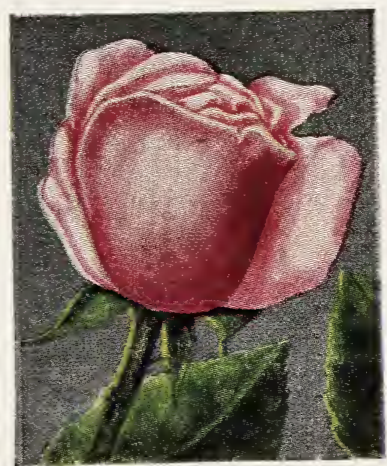

Pink Radiance.

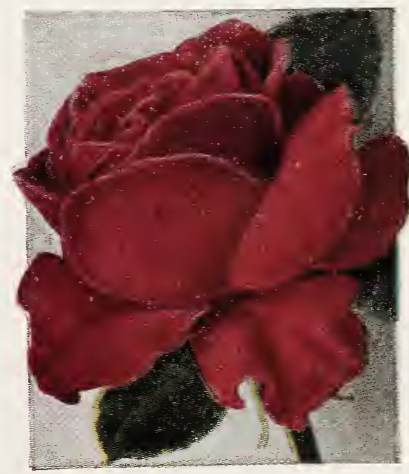

Etoile de France. 


\section{ORNAMENTAL TREES}

CHINESE ELM (Ulmus Pumila). Although a comparatively new introduction into the United States, this is a very popular tree. It is well adapted to use in practically every section of the country. The Chinese Elm is a very fast grower and is the most satisfactory tree to use where a quick shade is needed. Quite symmetrical and shape!y; foliage deep green. Used extensively for street planting.

\section{Size \\ PRICES}

3 to 4 feet................... $\$ .60 \quad \$ 5.50 \quad \$ 50.00$

4 to 5 feet.......................... $\quad .75 \quad 7.00 \quad 65.00$

5 to 6 feet................... $1.00 \quad 9.00 \quad 85.00$

6 to 8 feet.......................... $1.2510 .00 \quad \ldots$

8 to 10 feet..........................

10 to 12 feet..................... $2.00 \quad 17.50$

MAGNOLIA GRANDIFLORA. The native Magnolia so popular in the South. Large deep green, lustrous leaves which are evergreen; large white flowers blooming from April through August. Ultimate height, 50 to 75 feet. A most desirable tree, either for specimen or group planting.

\section{PRICES}

Size

Each

10

18 to 24 inch, bare root............. $\$ 1.25$

$\$ 10.00$

2 to 3 feet, bare root......................

12.50

3 to 4 feet.......................... 2.00

11.50

MIMOSA. Very attractive low growing tree with fine, feathery foliage. Pinkish flowers borne in great masses at the end of the branches in May. Holds blossoms several weeks. An excellent specimen subject.

\section{PRICES}

Size Each $10 \quad 100$

2 to 3 feet......................50 $\$ 4.50 \$ \$ 40.00$

3 to 4 feet......................... $75 \quad 7.00 \quad 65.00$

4 to 5 feet.......................... $1.00 \quad 9.00 \quad 80.00$

5 to 6 feet...................................

6 to 8 feet........................... $1.7515 .00 \quad \ldots \ldots$

RED BUD (Cercis Canadensis). Very spectacular in early spring, before the leaves appear, when the tree is covered with a mass of reddish-purple flowers. Fast growing, well shaped tree with large heart-shaped leaves.

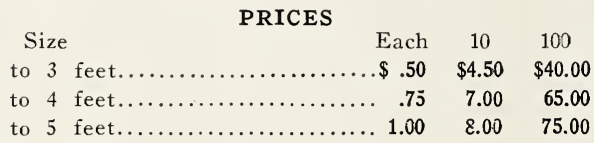

SYCAMORE. Well known in the South, where it is often used for street planting. Fast growing, symmetrical. Attractive bronze-green leaves.

\section{PRICES}

Size Each

6 to 8 feet.......................... \$2.00

$\$ 17.50$

8 to 10 feet......................... 2.50

22.50

DOGWOOD (Cornus Florida). The surest sign of spring in the South is the blossoming of the lovely dogwood. Striking in the fall with its manycolored Autumn leaves and red berries. Altogether the most desirable flowering tree. Our nursery. grown trees have far better root system than woods-grown trees and will give better results.

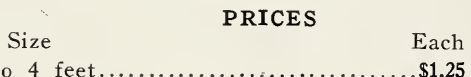

3 to 4 feet......................... $\$ 1.25$

4 to 5 feet........................ 1.75

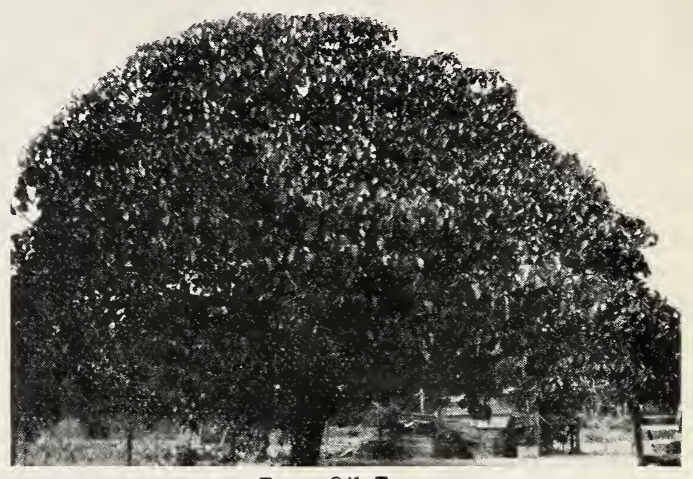

Tung Oil Tree.

\section{TUNG OIL TREES}

ALEURITES FORDII. The Chinese tung oil tree was introduced into this country from China some twenty years ago. It is valuable for its oil which is used in paints, varnishes, lacquers, and in a rapidly increasing number of commercial products. Hardy in South Georgia and Florida where it is sure to play an important part in their development. There is a great demand for the oil, practically all of which is now imported from China. The tree is of rapid growth, and even as an ornamental is attractive for its symmetrical growth and beautiful foliage. Our trees (about 6,003) for setting during the winter of 1929-30 are already nearly all sold; but we shall have a good lot for 1930-31. Suggest making reservations now for 1930 31. Write for circular giving further information.

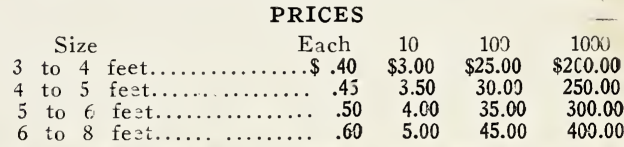

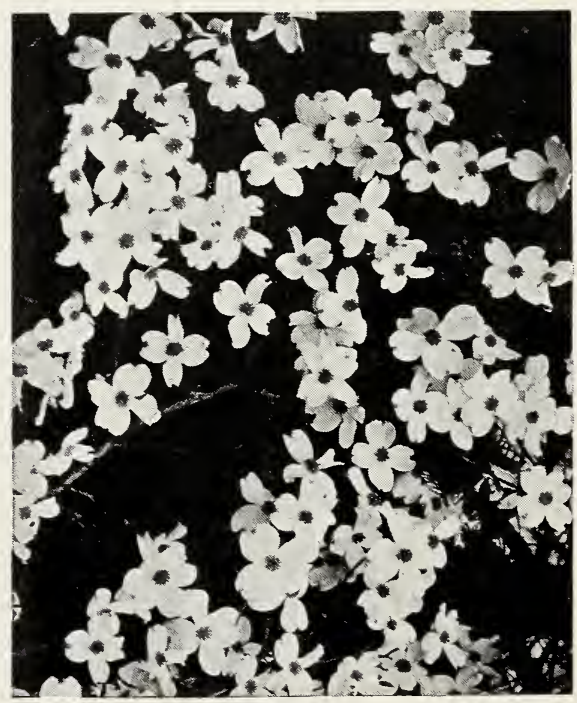

Dogwood. 


\section{ORDER BLANK}

NOTICE-If remittance does not accompany order, shipment will be made C. O. D. unless references are furnished. In all cases one-fourth of the amount must accompany order.

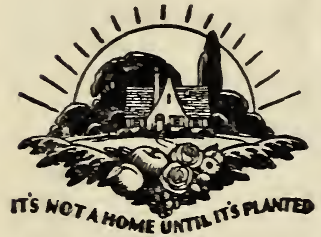

Street Address or R. F. D.

Town

Date.

\section{Amount Enclosed \$}

\section{To WIGHT NURSERY \& ORCHARD CO., CAIRO, GEORGIA}

State.

Ship Via

County.

(Write "Express," "Freight," or "Use Your Discretion")

It is understood that this order is given subject to stock being sold and no liability is to be attached to WIGHT NURSERY \& ORCHARD CO. when frost, drought or other conditions beyond their control prevent deivery of stock.

SUBSTITUTIONS-We do not substitute unless authorized to do so. If in doubt as to the best varieties to set, this, when left to us, will receive our careful attention, thus insuring a better selection than an inexperienced grower could make for himself.

Signature of Customer.

Address of Customer.

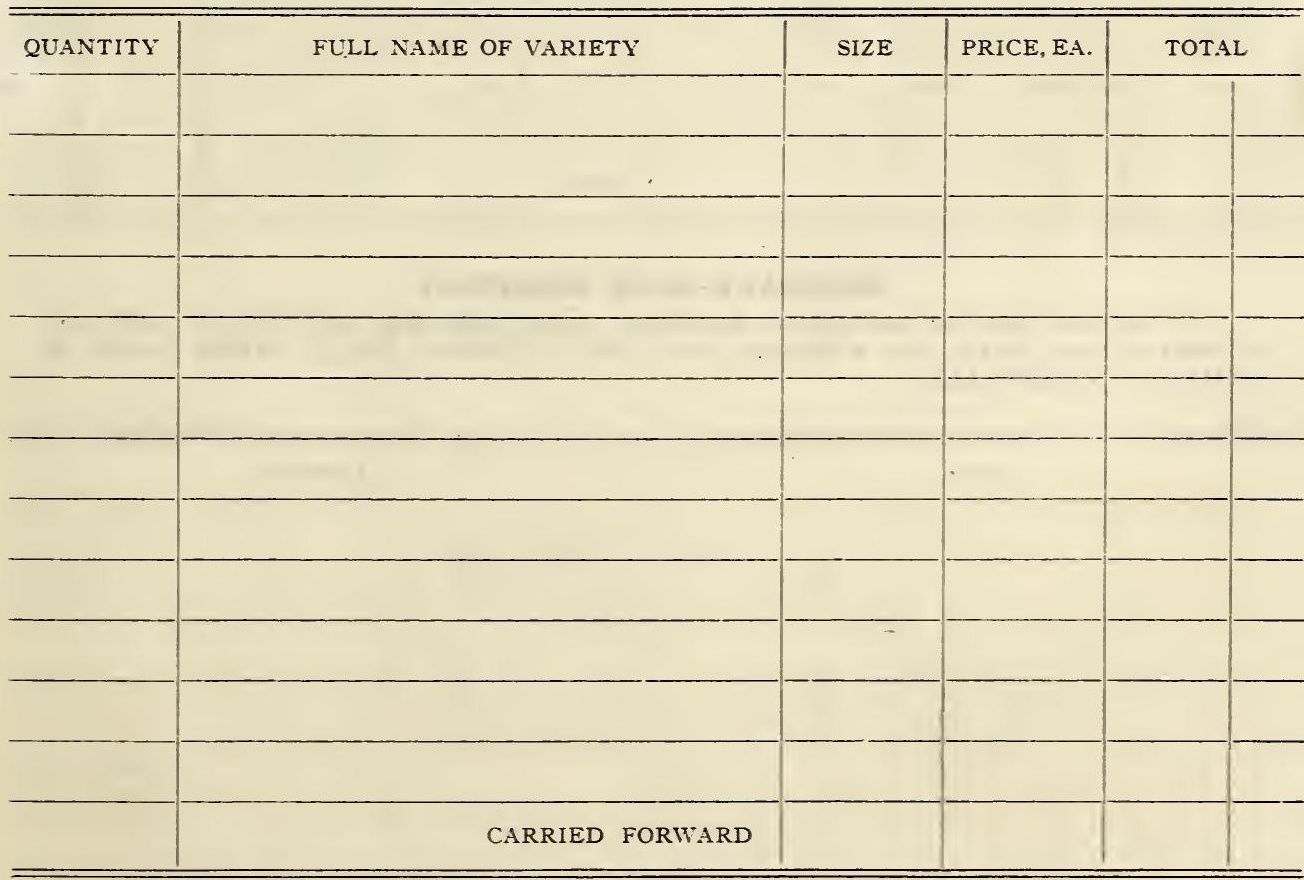


Wight Nursery \& Orchard Co. - ORDER BLANK - Cairo, Georgia

\begin{tabular}{|c|c|c|c|c|}
\hline QUANTITY & FULL NAME OF VARIETY & SIZE & PRICE, EA. & TOTA \\
\hline & BROUGHT FORWARD & 4 & & \\
\hline & 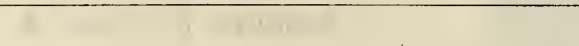 & & 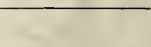 & 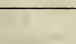 \\
\hline - & & & & \\
\hline & 1. & & & \\
\hline & & & & \\
\hline & 4 tring & & & \\
\hline 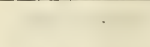 & $r^{\prime}$ & - & at & \\
\hline 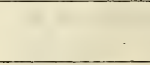 & $\begin{array}{c}1 \\
. \\
\end{array}$ & & 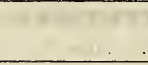 & 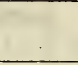 \\
\hline & 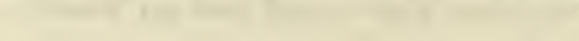 & . & 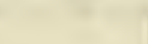 & \\
\hline & & & : : & \\
\hline & & & & \\
\hline & $+x$ & (1) & 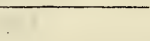 & $\because$ \\
\hline & & & & \\
\hline & TOTAL & & & \\
\hline
\end{tabular}

IMPORTANT-READ CARFFUTIY

We wish to send our catalogue to interested parties, and shall appreciate the addresses of some of your friends who would like to set PECAN TREES, FRTIT TREES, POSES or OTHER ORNAMENTALS. 


\section{Plants for Screens}

Arborvitae, American (Thuya Occidentalis)

Arborvitae, Oriental (T. Orientalis).

Bush Honeysuckle, all varieties listed.

Cherry Laurel (Laurocerasus Caroliniana).

Deutzia, all.

Forsythia, all.

Iigustrum Japonicum.

Ligustrum Lucidum.

\section{Shrubs for Adverse City Conditions}

\author{
Althca. \\ Arborvitae, all. \\ Junipers. \\ Acneysuckle, Winter (Lonicera Fragran- \\ tissima). \\ Forsythias. \\ Mock Orange (Philadelphus) \\ Pearlbush (Exochorda Grandiflora) \\ Spirea Van Houtte. \\ Viburnums.
}

\section{Plants for the Shade}

\section{Abelia Grandiflora.}

Azaleas.

Cherry Laurel (Laurocerasus Caroliniana).

Dogwood (Cornus Florida).

Goldenbells (Forsythia).
Holly, American.

Honeysuckle, Bush

Japonica (Camellia Japonica)

Jasmine (Jasminum Primulinum).

Ligustrums.

Riagnolia Grandiflcra.

Pittcsporum Tobira,

\section{Hedge Plants}

FLOWERING HEDGES, INFORMAL UUTLINE

Abelia Granditlora.

Althea.

Azaleas.

Deutzia.

Honeysuckle, Bush.

Orange, Hardy (Citrus Trifoliata).

Orange, Mock (Philadelphus).

Rose, Louis Phillippe.

Spirea, Thunberg and Van Houtte.

\section{Broad-Leaved Hedges, Formal Outline}

Abelia Grandiflora.

Euonymous Japonicus.

Ligustrum Ovalifolium Aurea.

Ligustrum Lucidum.

Pittosporum Tobira.

Tea Plant (Thea Bohea.)

\section{N D E X}

\section{A \\ Page}

Abelia ......................

Aleurites Fordii ..............30

Althea .......................22

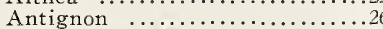

Apples $\quad . . \ldots \ldots \ldots \ldots \ldots \ldots \ldots \ldots . . .11$

Arborvitae ...................18

Azaleas ...................13, 14

B

Beauty Berry ................22

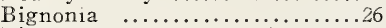
Biota .................... Thee Tha Broadleaved Evergreens...15, 16, 17 Buddlea .....................23 Butterfly Bush ...................23

\section{$\mathrm{C}$}

Camellia

C

Camphor .....................15

Cedar $\ldots \ldots \ldots \ldots \ldots \ldots \ldots \ldots \ldots \ldots \ldots \ldots \ldots . .19$

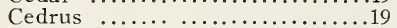

Cercis .........................

Cherry Laurel ................15

Cinnamomum Camphora ........15

Club Orders ...................

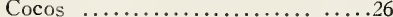

Conifers ...................18-21

Coral Vine .................26

Cornus Florida ..................

Crape Myrtle .................

Cupressus ..................... 19

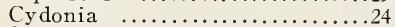

Cypress .....................19

\section{D}

Deutzia

.

Dogwood ...........................30

E

Elm, Chinese .................30

Euonymous $\ldots . . \ldots \ldots \ldots \ldots \ldots \ldots \ldots . . . .11$

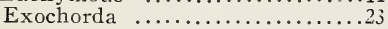

F

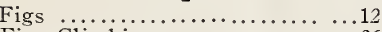

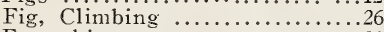

Forsythia $. . . . \ldots \ldots \ldots \ldots \ldots \ldots . . .23$

Fruits .. ...................

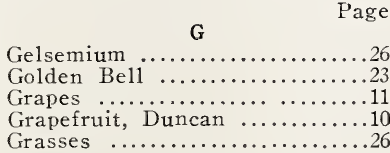

$\mathrm{H}$

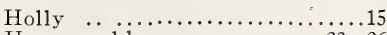
Honeysuckle ................. 26

\section{I}

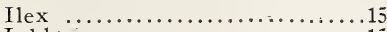

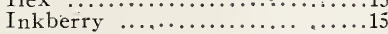

\section{$\mathrm{J}$}

Japonicas .....................16

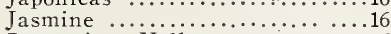
Jessamine, Yellow ...............26

Junipers .......................20

$\mathrm{K}$

Kudzu ...................11, 26

Kumquat .................... 10

L

Lagerstroemia $\ldots \ldots \ldots \ldots \ldots \ldots .22$

Laurocerasus ...................15

Ligustrum ..................16

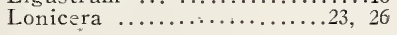

A 3

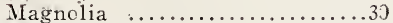

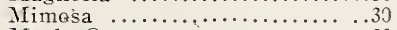

Mock Orange .....................

Nulberry, French ...........22

N
Nandina $\ldots \ldots . . . \ldots \ldots \ldots . . .16$

O

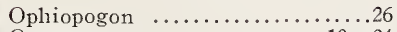

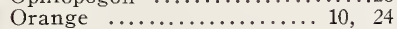

Osmanthus $\ldots \ldots \ldots \ldots \ldots \ldots \ldots \ldots . . .17$

\section{$\mathbf{P}$}

Page

Palms, Hardy $\quad$...............26

Peaches $. \ldots \ldots \ldots \ldots \ldots \ldots \ldots, 7,23$

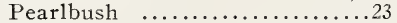

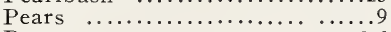

Pecans $. \ldots \ldots \ldots \ldots \ldots \ldots \ldots \ldots .2-6$

Persimmons, Japan ............9

Philadelphus ..................23

Phoenix Canariensis ..........26

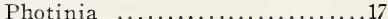

Pittosporum ....................

Plant, When To...............

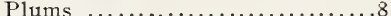

Podocarpus ...................21

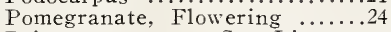

Privet ............. See Ligustrum

Pueraria ....................26

$Q$

Quince, Flowering

.24

$\mathrm{R}$

Red Bud .......................

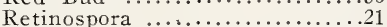

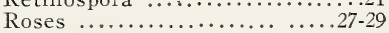

$\mathrm{S}$

Snake's Beard..$\ldots \ldots \ldots \ldots \ldots .26$

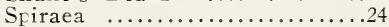

Sycamore $. . . \ldots \ldots \ldots \ldots \ldots . . . . .30$

\section{T}

Tea Olive ....................17

Tea Plant ......................

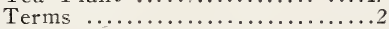

Thea Bohea .....................

Thuja.$\ldots \ldots \ldots \ldots \ldots \ldots \ldots \ldots 18$

Trees, Ornamental ............30

Trumpet Creeper ..............26

Tung Oil ........................30

$\mathrm{U}$

U1mus

Viburnum

$\mathrm{V}$ 


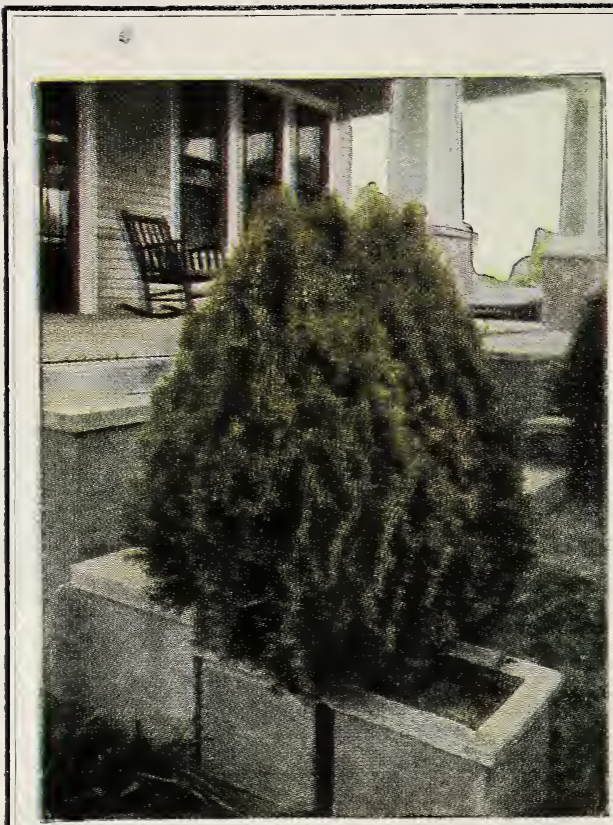

\section{Wight Nursery} and

\section{Orchard Co.}

\section{CAIRO - GEORGIA}

\section{SPECIAL OFFER No. 1}

We have some large deciduous plants, a small block of them, which must be moved this season to make room for other stock. To do this, we are willing to offer them at a price considerably below what this excellent stock would normally be sold. Some of these plants will run 6 to 8 feet-good, heavy, stocky material. Excellent for screening those unsightly out-houses or for the shrub border around the outdoor living room. Here they are:

4 Deutzia, largest size.

4 Forsythia, largest size.

4 Bush Honeysuckle, largest size.

6 Spirea Van Houtte, largest size.

18 plants, largest size, for only.... $\$ 5.95$

Berckman's Gclden Arborvitae.

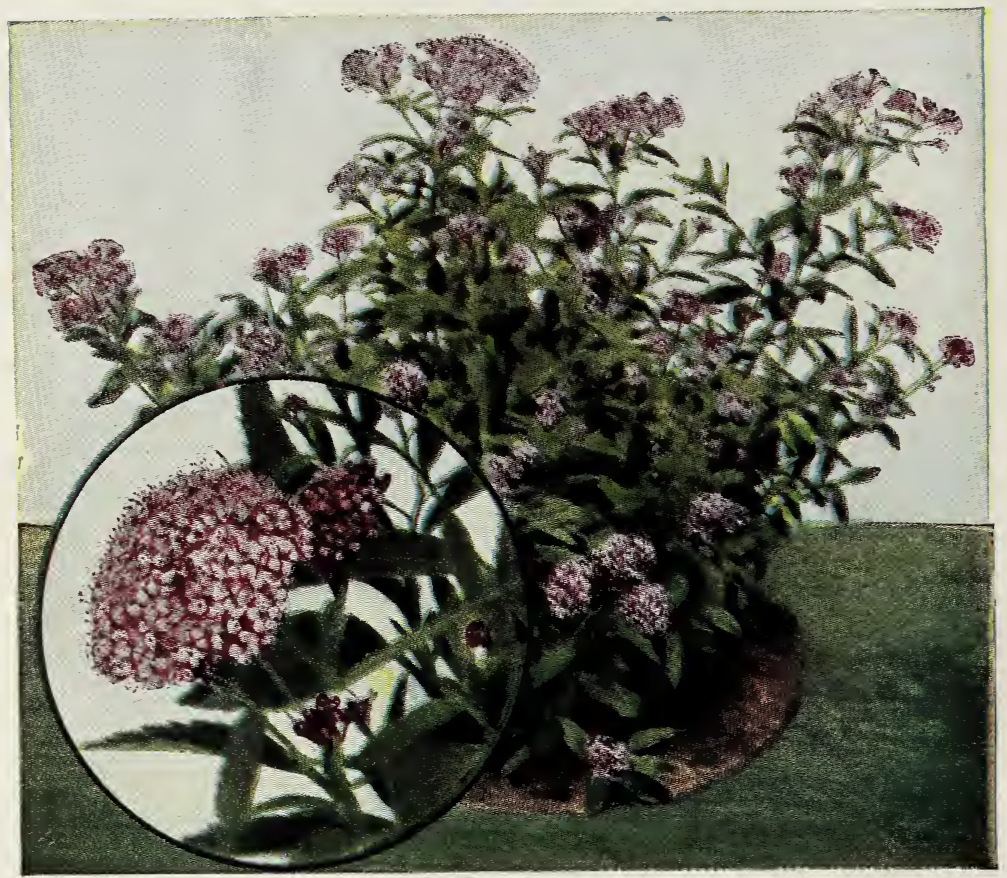

Spirea Anthony Waterer. 